Proc. Estonian Acad. Sci. Biol. Ecol., 2005, 54, 2, 83-119

\title{
On the mechanism of the phototoxic action of haematoporphyrin derivative towards tumour cells
}

\author{
Lyudmila Chekulayeva, Igor Shevchuk ${ }^{*}$, and Vladimir Chekulayev \\ Department of Chemistry, Tallinn University of Technology, Akadeemia tee 15, 12618 Tallinn, \\ Estonia
}

Received 9 March 2004, in revised form 20 May 2004

\begin{abstract}
The aim of this study was to estimate the participation of reactive oxygen species (ROS), other than singlet oxygen $\left({ }^{1} \mathrm{O}_{2}\right)$, in the antitumour effect of photodynamic therapy (PDT) with haematoporphyrin derivative (HPD) as well as to clarify the mechanism of the potentiating influence of heating associated with photoirradiation on the efficiency of this treatment. Our studies indicated that $\mathrm{H}_{2} \mathrm{O}_{2}$ and oxygen radicals could mediate the tumouricidal action of HPD-PDT; we found that photoirradiation of Ehrlich ascites carcinoma (EAC) cells pre-incubated with HPD leads to the formation of significant amounts of $\mathrm{H}_{2} \mathrm{O}_{2}$, superoxide $\left(\mathrm{O}_{2}^{-*}\right)$, and hydroxyl $\left(\mathrm{OH}^{*}\right)$ radicals, which along with ${ }^{1} \mathrm{O}_{2}$ were involved in photoinactivation of the cells in vitro. Furthermore, our experiments provided strong evidence that cell $\mathrm{Cu} / \mathrm{Zn}$ superoxide dismutase, catalase, and the glutathione redox cycle can protect tumour cells against the phototoxic influence of HPD. Our data support the view that in PDT the mild hyperthermia (around $44^{\circ} \mathrm{C}$ ) induced by irradiation can enhance synergistically the HPD-photoinduced tumour eradication; it was found that raising the irradiation temperature from 30 to $44^{\circ} \mathrm{C}$ caused a substantial $(\sim 1.5$-fold $)$ increase in the rate of HPD-photosensitized inactivation of EAC cells, whereas hyperthermia $\left(44^{\circ} \mathrm{C}\right)$ itself showed little toxic effects against the cells. Our results suggest that the potentiating effect of light-induced heating on the antitumour efficiency of HPD-PDT could be largely mediated by a heat-induced increase in the formation of cytotoxic ROS, such as $\mathrm{H}_{2} \mathrm{O}_{2}, \mathrm{O}_{2}{ }^{-}$, and $\mathrm{OH}^{*}$. Also, experiments showed that photosensitization of EAC cells by HPD caused a strong decrease in the activity of catalase and glutathione peroxidase, and that heat stress sensitized the $\mathrm{H}_{2} \mathrm{O}_{2}$-detoxifying enzymes to HPD-photoinduced inactivation; upon HPD-PDT, these events could result in loss of protection against accumulating $\mathrm{H}_{2} \mathrm{O}_{2}$. Moreover, our findings suggest that during PDT with HPD, an increase in the temperature of tumour tissues could enhance the efficiency of this therapy via the stimulation of a chlorin-type photoproduct formation.
\end{abstract}

Key words: antioxidant enzymes, heating, photodynamic therapy, reactive oxygen species, tumour.

Abbreviations: $\mathrm{BCNU}=1,3$-bis(2-chloroethyl)-1-nitrosourea; $\mathrm{BSA}=$ bovine serum albumin; $\mathrm{BSO}=\mathrm{D}$, L-buthionine-(S,R)-sulfoximine; $\mathrm{CAT}=$ catalase; $\mathrm{SOD}=$ superoxide dismutase; $\mathrm{DDC}=$ sodium diethyldithiocarbamate; $\mathrm{D}_{2} \mathrm{O}=$ deuterium oxide; $\mathrm{DEF}=$ deferoxamine mesylate; $\mathrm{DOR}=2$-deoxy-d-ribose;

*Corresponding author, igor@chemnet.ee 
$\mathrm{DTNB}=5,5^{\prime}$-dithiobis-2-nitrobenzoic acid EAC $=$ Ehrlich ascites carcinoma; EDTA $=$ ethylenediaminetetraacetic acid; GSH = reduced glutathione; $\mathrm{GSSG}=$ oxidized glutathione; $\mathrm{GPX}=$ glutathione peroxidase; $\mathrm{GR}=$ glutathione reductase; $\mathrm{HP}=$ haematoporphyrin; $\mathrm{HPD}=$ haematoporphyrin derivative; $\mathrm{H}_{2} \mathrm{O}_{2}=$ hydrogen peroxide; i.p. = intraperitoneal; $\mathrm{LD}_{50}=$ the light exposure time at which $50 \%$ of the cells were stained by trypan blue; $\mathrm{NADH}=$ reduced nicotinamide adenine dinucleotide; $\mathrm{NADPH}=$ reduced nicotinamide adenine dinucleotide phosphate; $\mathrm{NBT}=$ nitro blue tetrazolium; ${ }^{1} \mathrm{O}_{2}=$ singlet oxygen; $\mathrm{O}_{2}{ }^{-}=$superoxide radical; $\mathrm{OH}^{*}=$ hydroxyl radical; $\mathrm{PhP}-640=$ photoproduct-640; $\mathrm{PS}=$ photosensitizer; $\mathrm{PBS}=$ phosphate-buffered saline; $\mathrm{PDT}=$ photodynamic therapy; $\mathrm{PrSH}=$ proteinbound sulfhydryl groups; ROS $=$ reactive oxygen species; TBA $=2$-thiobarbituric acid; $\mathrm{TB}=$ trypan blue; $\operatorname{Trp}=$ tryptophan .

\section{INTRODUCTION}

Photodynamic therapy (PDT) is a relatively new approach for the treatment of oncological diseases that has the ability to selectively destruct neoplasias with only minimal side effects for the patient (Dougherty, 2002). It is based on the systemic administration of a tumour-localizing dye (photosensitizer, PS) that becomes toxic to target cells when activated by light at a specific wavelength in the presence of oxygen. Clinically the most frequently used PSs are haematoporphyrin derivative (HPD), a complex mixture of porphyrins prepared from haematoporphyrin (HP), and its more purified and active form, commercially known as Photofrin-II. Earlier studies on the mechanism of the action of HPD-PDT showed that this treatment modality may include a direct tumouricidal effect (damage of organelles within malignant cells) as well as destruction of blood vessels in the tumour locus resulting in reduced supply of oxygen and nutrients (Star et al., 1986; Shevchuk et al., 2002). Besides, it was reported that local immune reactions, e.g. macrophages, could be also responsible for the tumour necrotizing action induced by HPD-PDT (Evans et al., 1990). Although to date a number of patients with tumours of practically all histological types and in many locations have been treated with encouraging results by PDT with HPD or Photofrin-II (Dougherty, 2002), the fundamental mechanisms by which PDT kills tumour cells as well as its optimal physical parameters are still incompletely determined.

The photoexcited HPD is an efficient producer of singlet oxygen $\left({ }^{1} \mathrm{O}_{2}\right)$ in simple chemical systems (Tanielian et al., 2001) and it was suggested (Weishaupt et al., 1976) that this highly active oxidant is the main damaging agent in PDT. Nevertheless, there are some indications that besides ${ }^{1} \mathrm{O}_{2}$ other reactive oxygen species (ROS), such as hydrogen peroxide $\left(\mathrm{H}_{2} \mathrm{O}_{2}\right)$ and superoxide $\left(\mathrm{O}_{2}^{-}\right)$, and hydroxyl $\left(\mathrm{OH}^{\circ}\right)$ radicals, might be involved in the HPD-PDT induced tumour eradication (Hariharan et al., 1980; Das et al., 1985; Athar et al., 1988). However, the significance of $\mathrm{H}_{2} \mathrm{O}_{2}$ and oxygen radicals in the phototoxic action of HPD against tumour cells remains unclear as yet.

Although photochemical reactions of HPD seem to play a major role in the tumouricidal action of PDT, clinical trials (Berns et al., 1984) and the data obtained on animal models (Svaasand et al., 1983; Kinsey et al., 1983; Mattiello et al., 1987) 
showed that during a standard regime of PDT $(630 \mathrm{~nm}$ laser light at a power density of $\left.100-200 \mathrm{~mW} / \mathrm{cm}^{2}\right)$ a considerable $\left(5-13^{\circ} \mathrm{C}\right)$ increase in the temperature of tumour tissues can take place. Moreover, these researchers supposed that at least part of the result attributed to PDT with HPD could be mediated by a hyperthermic contribution, because the optical radiation utilized during the therapy can produce intratumoural temperatures that exceed the threshold of hyperthermic effects, i.e. greater than $41^{\circ} \mathrm{C}$; hyperthermia has proven to be selectively lethal to several kinds of malignant cells at temperatures in the range $41-46^{\circ} \mathrm{C}$ (Hildebrandt et al., 2002). The precise mechanisms leading to cell death following heat exposure are not clearly understood. Nevertheless, it is increasingly recognized that oxidative stress could be implicated in heat-induced cell death (Li \& Oberley, 1997; Lord-Fontaine \& Averill, 1999). Subsequently, more detailed studies on various experimental tumour systems clearly indicated that the thermal effects associated with photoirradiation may play a substantial role in the total cytotoxic effect of HPD-PDT and may potentiate (in a synergistic manner) the porphyrincatalysed photodestruction of tumour cells (Mang, 1990; Leunig et al., 1994; Uehara et al., 1996). However, until now the mechanism of the synergism remains unclear, although these observations resulted in the development of more effective treatment regimens in which HPD-based PDT is combined with a localized laseror microwave-induced hyperthermia immediately before or simultaneously with the phototherapy (Mang, 1990; Matsumoto et al., 1990). Several assumptions have been advanced to explain the potentiating effect of photoirradiation-induced heating on the efficiency of HPD-PDT. Namely, it was suggested that in PDT the hyperthermia produced by a laser irradiation could promote tumour destruction via an increase in the reactivity of the formed ${ }^{1} \mathrm{O}_{2}$ (Gottfried \& Kimel, 1991). Further, based on the model experiments with glyceraldehyde-3-phosphate dehydrogenase, Prinsze et al. (1991) proposed a mechanism for the synergistic interaction between HPD-PDT and hyperthermia in cancer treatment. Namely, their data suggest that even a minor photodamage of cellular proteins may cause a pronounced potentiation of their sensitivity to thermal denaturation; it is important to note that cell proteins are, as believed (Shevchuk et al., 2002), a principal target of PDT with HPD. As known, the sensitivity of tumour cells to the phototoxic action of HPD depends largely on the presence of oxygen. However, it was established that PDT with HPD can photochemically deplete ambient tumour oxygen, causing acute hypoxia and limiting treatment effectiveness (Henderson et al., 2000). Therefore, it was suggested that mild hyperthermia $\left(42-44^{\circ} \mathrm{C}\right)$ during PDT could improve the oxygenation status of tumours (due to a growth in tumour blood flow) and increase thereby the rate of tumour response to the therapy (Hetzel et al., 1994).

However, together with the aforementioned, other important processes could be responsible for a heat-induced increase in the sensitivity of tumour cells to the phototoxic action of HPD. We believe that besides its direct antitumour effect, the hyperthermia associated with photoirradiation could promote the formation of ${ }^{1} \mathrm{O}_{2}$ and/or other toxic ROS by activated molecules of the PS. Indeed, components 
of HPD are known to aggregate readily in certain solvents; in aqueous solution the PS exists as a complex mixture of nonaggregated or self-aggregated monoporphyrinic and oligomeric species (Tanielian et al., 2001). At the same time, in a prior study (Chekulayeva et al., 2002) we found that in aqueous buffer the dimers and larger aggregates of HPD can be disrupted by an increase in the temperature. Such a thermal disaggregation of HPD-moieties may presumably occur in tumour cells during PDT, resulting in higher yields of ${ }^{1} \mathrm{O}_{2}$ and oxygen radicals formation, since the nonaggregated molecules of the PS can easily come in contact with the surrounding molecules of oxygen. This assumption is supported by the data of Tanielian et al. (2001), who revealed that HPD in the aggregation state is a poor source of ${ }^{1} \mathrm{O}_{2}$. Additionally, a likely explanation for the potentiating action of lightinduced heating on the efficiency of HPD-PDT might be that the hyperthermic influence during PDT could make tumour cells more susceptible to oxidative damage due to an inhibition of the cellular repair enzymes activity and/or antioxidant systems of the cell. Numerous studies utilizing laser-induced fluorescence have demonstrated that HPD is destroyed (photobleached) during the PDT procedure (e.g. Mang et al., 1987). Under certain circumstances, notably when the initial concentration of HPD in the tumour is low, this photoprocess may limit the efficiency and applicability of PDT. However, our previous studies (Chekulayev et al., 1998) and the data of other researchers (Rotomskis et al., 1996) showed that illumination of HPD in aqueous buffer as well as in tumour cells leads to the formation of a photoproduct with peak absorption around $640 \mathrm{~nm}$ and peak fluorescence emission around $644 \mathrm{~nm}$. Comprehensive studies on HPD led to the suggestion that the photoproduct with an absorption band at $640 \mathrm{~nm}$ (photoproduct-640, PhP-640) is a chlorin or a covalently linked porphyrin-chlorin system (Rotomskis et al., 1996). Moreover, it was reported (Giniunas et al., 1991) that PhP-640 may take part in the PDT-induced tumour eradication, since it absorbs the radiation of light sources commonly used in clinical treatment and may act as a PS. So, if the heating of tumours during PDT promotes the formation of PhP-640, it might be expected that this event could be also responsible for a heat-induced increase in the efficiency of PDT with HPD. However, these assumptions need experimental checking.

Thus, the aim of this study was to assess the significance of $\mathrm{H}_{2} \mathrm{O}_{2}$ and oxygen radicals in the phototoxic action of HPD against tumour cells as well as to elucidate the mechanism of the potentiating influence of photoirradiation-induced heating on the efficiency of PDT with HPD.

\section{MATERIALS AND METHODS}

\section{Chemicals}

Deferoxamine mesylate (DEF), deuterium oxide $\left(\mathrm{D}_{2} \mathrm{O}\right), \mathrm{H}_{2} \mathrm{O}_{2}(30 \%$, w/v), bovine serum albumin (BSA; fatty acids free), $\mathrm{Cu} / \mathrm{Zn}$ superoxide dismutase $(\mathrm{Cu} / \mathrm{Zn}-\mathrm{SOD}$; from bovine erythrocytes, 3300 units $/ \mathrm{mg}$ protein), catalase (CAT; from bovine 
liver, thymol free, 16700 units/mg protein), and other chemicals (of analytical grade or better) were purchased from Sigma, St. Louis, USA, unless noted otherwise. HPD was synthesized from HP dihydrochloride as described in (Kessel et al., 1987). The obtained product was diluted with $0.9 \% \mathrm{NaCl}$ solution $(\mathrm{pH} 7.4)$ to a final porphyrin concentration of $5 \mathrm{mg} / \mathrm{mL}$, and stored in the dark at $-20^{\circ} \mathrm{C}$. Working solutions of HPD $(0.5 \mathrm{mg} / \mathrm{mL})$ were prepared immediately before use by the further diluting of the stock solution with a medium (see below). In the work, all solutions were sterilized by filtration through $0.22 \mu \mathrm{m}$ filter units.

\section{Animals and cells}

White mongrel three-month-old female mice obtained from the National Institute for Health Development (Tallinn, Estonia) were used in the experiments. The animals were fed ad libitum on standard pellets and had permanent access to water. Ehrlich ascites carcinoma (EAC) cells obtained from the National Institute of Chemical Physics and Biophysics (Tallinn, Estonia) were maintained by intraperitoneal (i.p.) transplantation of $0.2 \mathrm{~mL}$ ascites fluid $\left(\sim 2.5 \times 10^{7}\right.$ cells $)$ from mouse to mouse every 7 days.

\section{Light source}

In all the experiments a voltage regulated $1 \mathrm{~kW}$ xenon arc lamp equipped with a parabolic mirror and glass filters (KS-10 together with SZS-25) to deliver the light at $630 \mathrm{~nm}$ (the range between 590 and $830 \mathrm{~nm}$ ) served as the radiation source (the infrared radiation was removed by a $4 \mathrm{~cm}$ water filter). The flux of the light was focused as a spot $\left(2.54 \mathrm{~cm}^{2}\right)$ and directed on the front face of a quartz cuvette containing EAC cell suspension or HPD solutions. In some experiments, EAC cells and HPD solutions were also irradiated with green light at $510 \mathrm{~nm}$ (the range between 480 and $570 \mathrm{~nm}$ ). The intensity of the emitted light at 510 and $630 \mathrm{~nm}$ was always $260 \mathrm{~mW}$ with a power density of $102 \mathrm{~mW} / \mathrm{cm}^{2}$, as measured by an IMO-2N radiometer (Russian Federation).

\section{Preparation of cell suspensions, the irradiation conditions, and cytotoxicity assay}

Six to seven days old EAC cells were withdrawn from the sacrificed animals and suspended in phosphate-buffered saline (PBS) containing $154 \mathrm{mM} \mathrm{NaCl}$, $6.2 \mathrm{mM} \mathrm{KCl}, 5.55 \mathrm{mM}$ glucose, and $10 \mathrm{mM}$ sodium phosphate buffer ( $\mathrm{pH} 7.3$ ). The cells were centrifuged at $600 \mathrm{~g}$ for $5 \mathrm{~min}$ at $4{ }^{\circ} \mathrm{C}$, washed twice, counted, and resuspended in PBS at a concentration of $4 \times 10^{7}$ cells $/ \mathrm{mL}$. The viability of the cells was about $95-98 \%$ as found by light microscopy in the presence of trypan blue (TB). Further, the cells were loaded with HPD. For this purpose, an aliquot 
of the cell suspension $\left(4 \times 10^{7}\right.$ cells $\left./ \mathrm{mL}\right)$ was placed into a plastic flask (Nunclon, Denmark), and after the addition of HPD (up to a final concentration of $20 \mu \mathrm{g} / \mathrm{mL}$ ) the cells were incubated for $25 \mathrm{~min}$ in the dark at $30^{\circ} \mathrm{C}$ with shaking at 80 oscillations/min. At the end of the incubation, the cell suspension was transferred quantitatively to a $10-\mathrm{mL}$ centrifuge tube, and the cells were sedimented by centrifugation at $2800 \mathrm{rpm}$ for $5 \mathrm{~min}$ at $4{ }^{\circ} \mathrm{C}$. The supernatant containing the unbound fraction of HPD was removed by aspiration, whereas the packed cells were resuspended in PBS at a concentration of $4 \times 10^{7}$ cells $/ \mathrm{mL}$ and kept in an ice bath until use. For the simultaneous thermal and PDT treatment, the cells loaded with HPD were diluted with PBS that was pre-heated in a water bath to a desired temperature (from 10 to $44^{\circ} \mathrm{C}$ ). An $8 \mathrm{~mL}$ sample of the cell suspension $\left(5 \times 10^{6}\right.$ cells $\left./ \mathrm{mL}\right)$ was quickly transferred into a $2 \times 2 \mathrm{~cm}$ quartz cuvette and a microstirring magnet was added. The cuvette with the cells was then placed in a thermostatted (by circulating water) holder and illuminated in air with stirring at different temperatures, which were maintained within the error limits of $\pm 0.5^{\circ} \mathrm{C}$. The time interval between the introduction of the cells into the pre-heated PBS and the beginning of light exposure was $5 \mathrm{~min}$.

Cytotoxicity was determined by the TB exclusion assay. Immediately after photoirradiation, an aliquot of the cell suspension $\left(5 \times 10^{6}\right.$ cells $\left./ \mathrm{mL}\right)$ was diluted $1: 1(\mathrm{v} / \mathrm{v})$ with $0.2 \% \mathrm{~TB}$, and 2 min later the cells were counted using a Goryaev's chamber. Results are expressed as the percentage of dead cells calculated as the ratio of TB-stained versus the total number of cells.

\section{Assessment of cell respiration}

The respiration of EAC cells $\left(1 \times 10^{7}\right.$ cells $/ \mathrm{mL}$ in air-saturated PBS $)$ was estimated by measuring the rate of oxygen consumption by the cells using a Clark-type oxygen electrode. The measurements were performed in a waterthermostatted incubation chamber under continuous magnetic stirring at a required temperature.

\section{Depletion of glutathione in EAC cells}

This was achieved by treatment of the cells with D, L-buthionine-(S,R)sulfoximine (BSO), a potent inhibitor of glutathione biosynthesis (Bailey, 1998), using in vivo protocols. These experiments were performed on eight female mice to which $0.2 \mathrm{~mL}$ EAC was injected i.p. On the sixth day after the tumour inoculation, some of the animals were injected i.p. with BSO (up to $4 \mathrm{mM} / \mathrm{kg}$ body weight) dissolved in $0.9 \% \mathrm{NaCl}$. Control animals with the tumour received an i.p. injection of $0.9 \% \mathrm{NaCl}$. Fourteen hours later, the EAC cells from control and BSO-treated mice were removed by aspiration, washed twice with PBS, and the levels of glutathione in these cells were measured as described below. 
Determination of the intracellular content of $\mathrm{NAD}(\mathrm{P}) \mathrm{H}$, tryptophan, protein-bound sulfhydryl groups, and reduced and oxidized glutathione

Since the reduced forms of nicotinamide adenine dinucleotide (NADH) and nicotinamide adenine dinucleotide phosphate (NADPH) are mainly responsible for the fluorescence band at $470 \mathrm{~nm}$ in normal as well as tumour cells (Lohmann \& Paul, 1988), the content of NAD(P)H in EAC cells was estimated fluorometrically. Namely, during HPD-PDT the fluorescence of the cell suspension $\left(5 \times 10^{6}\right.$ cells $/ \mathrm{mL}$ in PBS) at $470 \mathrm{~nm}$ (excitation at $\left.340 \mathrm{~nm}\right)$ was measured in a $10 \times 10 \mathrm{~mm}$ quartz cuvette under magnetic stirring with $5 \mathrm{~nm}$ bandwidths for excitation and detection. In the work, all fluorescence measurements were performed by a Hitachi 650-60 fluorescence spectrophotometer (Japan).

The tryptophan (Trp) content of cellular proteins was estimated by the method of Spies \& Chambers with $p$-dimethylaminobenzaldehyde exactly as described in (Shevchuk et al., 2002), whereas protein-bound sulfhydryl groups ( $\mathrm{PrSH})$ were assayed by the method of Ellman with 5,5'-dithiobis-2-nitrobenzoic acid (DTNB) as described in (Edwards, 1988).

Reduced glutathione (GSH) and its oxidized form (GSSG) were measured by the fluorometric method of Hissin \& Hilf (1976). Briefly, GSH in the acid-soluble supernatant fraction of EAC cells was reacted with $o$-phthaldialdehyde (Fluka BioChemica, Germany) at $\mathrm{pH} 8$ to yield a highly fluorescent cyclic product, while GSSG was determined by the same reagent but at $\mathrm{pH} 12$ and in the presence of N-ethylmaleimide.

\section{Determination of superoxide radical}

The intracellular levels of $\mathrm{O}_{2}{ }^{-}$were measured using an adaptation of the method employed by Rothe \& Valet (1990). We used the dye hydroethidine (HE; Fluka BioChemica, Germany) that is oxidized by $\mathrm{O}_{2}{ }^{-}$within the cell to produce ethidium bromide, which emits red fluorescence after intercalation into DNA. Briefly, following photoirradiation EAC cells (at a density of $1.5 \times 10^{6}$ cells $/ \mathrm{mL}$ in PBS) were incubated with $10 \mu \mathrm{M}$ HE (made as a $10 \mathrm{mM}$ stock solution in $\mathrm{N}, \mathrm{N}$-dimethylformamide) for $15 \mathrm{~min}$ in a shaking water bath at $37^{\circ} \mathrm{C}$. After the incubation, the fluorescence from ethidium bromide in the cells was measured at $610 \mathrm{~nm}\left(\lambda_{\mathrm{ex}}=488 \mathrm{~nm}\right)$ in $1 \times 1 \mathrm{~cm}$ quartz cuvettes; slits were 5 and $15 \mathrm{~nm}$ for excitation and emission, respectively. The blank corresponding to HE alone in the buffer was subtracted from the value.

The ability of photoexcited HPD to the generation of $\mathrm{O}_{2}{ }^{-}$was also examined in aqueous buffer. In these studies, the formation of $\mathrm{O}_{2}{ }^{-}$was assayed by monitoring the photoinduced reduction of nitro blue tetrazolium (NBT). The reduction of NBT by $\mathrm{O}_{2}{ }^{-}$leads, as known, to the formation of a blue-coloured formazan that can be quantitatively estimated spectrophotometrically at $560 \mathrm{~nm}, \varepsilon=15000 \mathrm{M}^{-1} \mathrm{~cm}^{-1}$. Unless indicated otherwise, reaction mixtures were $10 \mu \mathrm{g} / \mathrm{mL}$ in HPD, $10 \mathrm{mM}$ in sodium phosphate buffer ( $\mathrm{pH} 7.3$ ), and $0.16 \mathrm{mM}$ in NBT. 


\section{Assay for $\mathrm{H}_{2} \mathrm{O}_{2}$ and $\mathrm{OH}^{\cdot}$ generation}

The production of $\mathrm{H}_{2} \mathrm{O}_{2}$ during photodynamic treatment of EAC cells with HPD was estimated by measuring of its concentration in cell free supernatants. Namely, immediately after light exposure aliquots $(0.2 \mathrm{~mL})$ of the cell suspension $\left(5 \times 10^{6}\right.$ cells $/ \mathrm{mL}$ ) were placed into pre-cooled (on melting ice) plastic tubes. Further, the cells were precipitated on an Eppendorf table centrifuge at maximal speed ( $8500 \mathrm{~g}$, for $4 \mathrm{~min}$ at room temperature), and the concentration of $\mathrm{H}_{2} \mathrm{O}_{2}$ in the supernatants was determined by the method of Keston \& Brandt (1965) based on the oxidation of nonfluorescent leukodiacetyl-2,7-dichlorofluorescin to a fluorescent compound by $\mathrm{H}_{2} \mathrm{O}_{2}$ in the presence of horseradish peroxidase.

The generation of $\mathrm{OH}^{*}$ during photodynamic treatment of EAC cells with HPD was estimated by the 2-deoxy-d-ribose (DOR) method of Gutteridge (1981); the sugar is oxidized by $\mathrm{OH}^{-}$with the formation of products, which upon heating with 2-thiobarbituric acid (TBA) at low $\mathrm{pH}$ yield a pink chromogen. In our studies, the TBA-reactive products of DOR were determined as described previously in (Gutteridge, 1981; Girotti \& Thomas, 1984) with minor modifications. Briefly, during the whole irradiation procedure aliquots $(0.3 \mathrm{~mL}$, typically containing $3 \mu$ moles of DOR) of the cell suspension $\left(5 \times 10^{6}\right.$ cells $/ \mathrm{mL}$ in PBS) were collected into test tubes with $0.9 \mathrm{~mL}$ of $154 \mathrm{mM} \mathrm{NaCl}$. After the addition of $0.2 \mathrm{~mL}$ of cold $15 \%$ trichloroacetic acid solution, the samples were vortexed and stored on an ice bath for $20 \mathrm{~min}$. The tubes with the samples were then centrifuged and $0.8 \mathrm{~mL}$ of $1 \%$ TBA in $0.05 \mathrm{M} \mathrm{NaOH}$ was added to $0.9 \mathrm{~mL}$ of the supernatant. These samples were heated at $100^{\circ} \mathrm{C}$ for $15 \mathrm{~min}$, cooled rapidly to room temperature, and their fluorescence was read at $553 \mathrm{~nm}$ (excitation at $532 \mathrm{~nm}$ ). The obtained results were expressed as relative fluorescence units against a standard containing rhodamine $\mathrm{B}(1.0 \mu \mathrm{M}$, in $10 \mathrm{mM}$ sodium phosphate buffer of $\mathrm{pH} 7.2)$. This standard was set to 100 units at excitation $480 \mathrm{~nm}$, emission at $580 \mathrm{~nm}$. In these experiments, the contribution of lipid peroxidation to TBA reactivity was negligible and the values were subtracted from those observed during HPD-PDT of EAC cells in the presence of DOR.

\section{Studies of photochemical transformations of HPD in EAC cells}

In these experiments, HPD-loaded EAC cells were diluted with PBS to a concentration of $5 \times 10^{6}$ cells $/ \mathrm{mL}$. Further, an $8 \mathrm{~mL}$ sample of the cell suspension was transferred into a $2 \times 2 \mathrm{~cm}$ thermostatted quartz cuvette and irradiated in air under magnetic stirring with red light at $630 \mathrm{~nm}$. During light exposure, the photodegradation of HPD in EAC cells and the formation of PhP-640 were monitored by fluorescence spectroscopy. Following photoirradiation, aliquots $(0.2 \mathrm{~mL})$ of cell suspension were withdrawn and placed into test tubes with $1.3 \mathrm{~mL}$ of $1.0 \mathrm{M} \mathrm{NaOH}$. One hour later, fluorescence spectra (excitation at $399 \mathrm{~nm}$ ) of the cell lysates were recorded using $1 \times 1 \mathrm{~cm}$ quartz cuvettes. The fall of lightinduced fluorescence of HPD in the $614 \mathrm{~nm}$ band was measured to determine 
the rate of its photodegradation in the cells, while the yields of PhP-640 formation were estimated by measuring the fluorescence of cell lysates at $644 \mathrm{~nm}$. The concentration of HPD in cell lysates was determined from a calibration curve, which was obtained by measuring the fluorescence of the known porphyrin concentration at $614 \mathrm{~nm}$ in $1.0 \mathrm{M} \mathrm{NaOH}$.

\section{Photodegradation of Trp and BSA in aqueous solution}

In these experiments, an $8 \mathrm{~mL}$ sample of a $10 \mu \mathrm{g} / \mathrm{mL}$ HPD solution (containing Trp or BSA) was placed into a $2 \times 2 \mathrm{~cm}$ quartz cuvette and irradiated in air under magnetic stirring with light at 510 or $630 \mathrm{~nm}$. Under photoexcitation of HPD, the absorbance (differential spectrum) of Trp at $280 \mathrm{~nm}$ was registered to determine the rate of its photooxidation, whereas the efficiency of HPD-photosensitized degradation of Trp residues in BSA was estimated fluorometrically by measuring the reduction of intrinsic fluorescence of this amino acid (excitation at $285 \mathrm{~nm}$ and emission at $345 \mathrm{~nm}$ ). The level of SH-groups in BSA was assessed by the reaction with DTNB according to the procedure of Sedlak \& Lindsay (1968) with minor modifications.

\section{Determination of enzyme activities}

Following HPD-PDT or pretreatment with corresponding inhibitors, EAC cells were lysed with $0.2 \%$ Triton X-100. Any non-solubilized material was removed by centrifugation, and the supernatant solutions were analysed for CAT, glutathione peroxidase (GPX), glutathione reductase (GR), or Cu/Zn-SOD activity.

The CAT activity was determined at $20^{\circ} \mathrm{C}$ according to the method of Aebi (1984). CAT decomposes $\mathrm{H}_{2} \mathrm{O}_{2}$ to give $\mathrm{H}_{2} \mathrm{O}$ and $\mathrm{O}_{2}$. The decomposition of $\mathrm{H}_{2} \mathrm{O}_{2}$ was followed by a decrease in the absorbance at $240 \mathrm{~nm}$. The reaction mixture contained $50 \mathrm{mM}$ sodium phosphate buffer ( $\mathrm{pH} 7.0$ ), $10 \mathrm{mM} \mathrm{H}_{2} \mathrm{O}_{2}$, and $\sim 150 \mu \mathrm{g}$ protein of cell lysate, the final volume was $1.5 \mathrm{~mL}$. CAT activity was expressed as $\mu$ moles $\mathrm{H}_{2} \mathrm{O}_{2}$ decomposed per min per mg protein, using an excitation coefficient of $43.6 \mathrm{M}^{-1} \mathrm{~cm}^{-1}$ for $\mathrm{H}_{2} \mathrm{O}_{2}$. The total cell proteins were determined by the well-known procedure with fluorescamine (Udenfriend et al., 1972) using BSA as the standard.

The activities of GR and GPX were determined at $37^{\circ} \mathrm{C}$. GR was measured essentially as described by Pinto \& Bartley (1969). The reaction mixture contained $50 \mathrm{mM}$ potassium phosphate buffer ( $\mathrm{pH} 7.4), 1.0 \mathrm{mM}$ ethylenediaminetetraacetic acid (EDTA), $0.2 \mathrm{mM}$ NADPH, $2.5 \mathrm{mM} \mathrm{GSSG}$, and cell sample ( $250 \mu \mathrm{g}$ protein), in a total volume of $1.5 \mathrm{~mL}$. The GR activity was determined by tracking the decrease in the absorbance of NADPH at $340 \mathrm{~nm}$ during the reduction of GSSG. The enzyme activity was expressed as nmoles NADPH oxidized per min per mg protein, using an excitation coefficient of $6.22 \mathrm{mM}^{-1} \mathrm{~cm}^{-1}$ for NADPH. The GPX activity was determined by the GR-coupled method reported by Paglia \& Valentine (1967), using $\mathrm{H}_{2} \mathrm{O}_{2}$ as the substrate. GPX catalyses the oxidation of GSH to GSSG by $\mathrm{H}_{2} \mathrm{O}_{2}$. The rate of GSSG formation was then measured by following a 
decrease in the absorbance of the reaction mixture containing NADPH and GR at $340 \mathrm{~nm}$ as NADPH is converted to NADP. The assay mixture contained $50 \mathrm{mM}$ potassium phosphate buffer ( $\mathrm{pH} 7.4), 1.0 \mathrm{mM}$ EDTA, 0.9 unit $/ \mathrm{mL}$ yeast GR, $1.0 \mathrm{mM}$ GSH, $0.15 \mathrm{mM}$ NADPH, $1.0 \mathrm{mM} \mathrm{NaN}_{3}$ (to inhibit CAT), $0.25 \mathrm{mM}$ $\mathrm{H}_{2} \mathrm{O}_{2}$, and $\sim 200 \mu \mathrm{g}$ protein of cell lysate; the final volume was $1.5 \mathrm{~mL}$. The GPX activity was calculated as nmoles NADPH oxidized per min per mg protein.

The activity of $\mathrm{Cu} / \mathrm{Zn}$-SOD was measured at $25^{\circ} \mathrm{C}$ by the method of Oberley \& Spitz (1984) that utilizes a xanthine-xanthine oxidase system to generate a superoxide flux and NBT as an indicator. The reaction mixture contained $50 \mathrm{mM}$ potassium phosphate buffer, $\mathrm{pH} 7.8 ; 1.0 \mathrm{mM}$ diethylenetriaminepentaacetic acid; $1.0 \mathrm{unit} / \mathrm{mL} \mathrm{CAT} ; 56 \mu \mathrm{M}$ NBT; $0.1 \mathrm{mM}$ xanthine; $0.02 \mathrm{unit} / \mathrm{mL}$ xanthine oxidase; and cell protein. The absorbance of the mixture at $560 \mathrm{~nm}$ increased as NBT was reduced by $\mathrm{O}_{2}^{-\bullet}$. The rate of NBT reduction in the absence of cell protein was used as the reference rate. When increasing amounts of cell protein (containing SOD activity) were added to the system, the rate of NBT reduction was progressively inhibited. One unit of SOD activity was defined as the amount of protein necessary to decrease the reference rate to $50 \%$ of maximum inhibition. $\mathrm{NaCN}(5 \mathrm{mM})$ was added (for $45 \mathrm{~min}$ ) to assay Mn-SOD activity. The Mn-SOD activity was subtracted from the total SOD activity to calculate the $\mathrm{Cu} / \mathrm{Zn}-\mathrm{SOD}$ activity that was expressed as units/mg protein.

\section{Statistics}

Results were analysed statistically by the Student's $t$-test. Values of $P<0.05$ were considered statistically significant. Data in the text, tables, and figures are presented as mean \pm standard error (SE) of at least 3 separate experiments.

\section{RESULTS AND DISCUSSION}

\section{Investigation of the participation of $\mathrm{H}_{2} \mathrm{O}_{2}$ and oxygen radicals in the eradication of tumour cells by HPD-PDT}

In this study, practically all in vitro experiments on the mechanism of HPDPDT were carried out at $30^{\circ} \mathrm{C}$ unless indicated otherwise. Figure 1 shows that under photoexcitation of HPD the time course of EAC cells inactivation was of S-type. In this work, the light exposure time at which $50 \%$ of the cells were stained by TB $\left(\mathrm{LD}_{50}\right)$ was utilized as a criterion to evaluate the efficiency of HPD-PDT induced cytotoxicity in vitro. It is important to note that photoirradiation of EAC cells in the absence of HPD, as well as their incubation with the PS in the dark at $30^{\circ} \mathrm{C}$, did not cause any noticeable increase in the number of dead cells.

There is much experimental evidence indicating that the cytotoxic action of HPD and light is mediated by the photosensitized production of ${ }^{1} \mathrm{O}_{2}$ via a Type II reaction (Weishaupt et al., 1976). On the other hand, some in vitro (Hariharan et al., 1980; Das et al., 1985) and in vivo studies (Athar et al., 1988) suggest the 


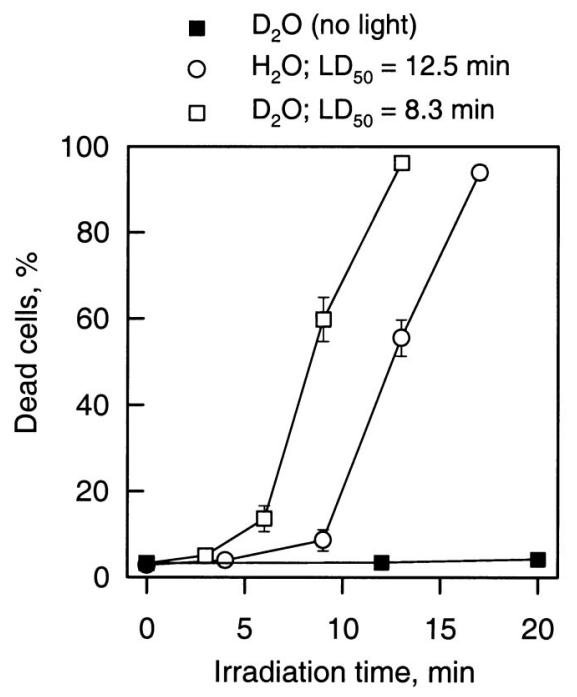

Fig. 1. The influence of $\mathrm{D}_{2} \mathrm{O}$ on the rate of HPD-photosensitized inactivation of EAC cells $\left(5 \times 10^{6}\right.$ cells $/ \mathrm{mL}$ ). Before irradiation, the cells were treated with HPD (at $20 \mu \mathrm{g} / \mathrm{mL}$ ) in PBS made of $\mathrm{H}_{2} \mathrm{O}$. Further, the cells loaded with HPD were brought into suspension in PBS made of either $\mathrm{H}_{2} \mathrm{O}$ or $99.8 \% \mathrm{D}_{2} \mathrm{O}$ and illuminated with red light at $630 \mathrm{~nm}$ (temperature was $30^{\circ} \mathrm{C}$ ). $\mathrm{LD}_{50}$ is the light exposure time at which $50 \%$ of the cells were stained by TB. Bars are SE as estimated from 3 independent experiments.

production of $\mathrm{H}_{2} \mathrm{O}_{2}, \mathrm{O}_{2}^{-}$, and $\mathrm{OH}^{\bullet}$ in cells and tissues exposed to visible light in the presence of HPD. However, in these published works it has not been proven unequivocally that these ROS are involved in the phototoxic action of HPD against tumour cells. For instance, Hariharan et al. (1980) using Chinese hamster V-79 cells demonstrated the generation of $\mathrm{OH}^{*}$ when the cells were exposed to HPD and red light, but these researchers did not investigate the contribution of this oxidant in the cytotoxicity resulting from photoexcited HPD. Therefore, it seemed important to assess the possibility that in addition to ${ }^{1} \mathrm{O}_{2}$ other ROS (such as $\mathrm{H}_{2} \mathrm{O}_{2}, \mathrm{O}_{2}{ }^{-}$, and $\mathrm{OH}^{*}$ ) might be involved in the phototoxic action of the sensitizer against tumour cells. In this relation, we performed a comparative study of the influence of $\mathrm{D}_{2} \mathrm{O}, \mathrm{CAT}$, as well as selective traps of certain oxygen radicals on the intensity of HPD-sensitized photoinactivation of EAC cells in vitro.

One of the most reliable methods to prove the participation of ${ }^{1} \mathrm{O}_{2}$ in photochemical processes is using $\mathrm{D}_{2} \mathrm{O}$ as a solvent. Replacing $\mathrm{H}_{2} \mathrm{O}$ by $\mathrm{D}_{2} \mathrm{O}$ must increase the efficiency of photochemical reactions proceeding via a Type II reaction, because the lifetime of ${ }^{1} \mathrm{O}_{2}$ in $\mathrm{D}_{2} \mathrm{O}$ is approximately 15 times greater than that in $\mathrm{H}_{2} \mathrm{O}$ (Bensasson et al., 1993). Our data (Fig. 1) showed that HPDphotosensitized inactivation of EAC cells is enhanced, in a synergistic manner, when the cells were suspended in $\mathrm{D}_{2} \mathrm{O}-\mathrm{PBS}$. This indicates that ${ }^{1} \mathrm{O}_{2}$ is involved in the inactivation. However, the potentiating effect of $\mathrm{D}_{2} \mathrm{O}$ was relatively small; in 
PBS made of $\mathrm{D}_{2} \mathrm{O}$ the $\mathrm{LD}_{50}$ value of HPD-PDT was decreased by a factor of about 1.5 as compared with cells suspended in PBS made of $\mathrm{H}_{2} \mathrm{O}$. Similar effects of $\mathrm{D}_{2} \mathrm{O}$ on the yield of photoinactivation of tumour cells were observed earlier by Moan et al. (1979), who used HP as a PS. HPD, as a lipophilic compound, is concentrated predominantly in plasma and subcellular membranes, making these structures especially sensitive to toxic photodamage. In this connection, we believe that the small effect of $\mathrm{D}_{2} \mathrm{O}$ on the rate of HPD-photoinduced injury of EAC cells could be explained by dissolution of the photodrug in membrane lipids where the lifetime of ${ }^{1} \mathrm{O}_{2}(50-100 \mu \mathrm{s})$ is close to that observed in $\mathrm{D}_{2} \mathrm{O}(\sim 60 \mu \mathrm{s})$ (Bensasson et al., 1993; Petrat et al., 2003). Another explanation for the effect of $\mathrm{D}_{2} \mathrm{O}$ would be that other ROS along with ${ }^{1} \mathrm{O}_{2}$ are involved in the cytotoxicity resulting from photoexcited HPD. Further studies confirmed this assumption. We revealed that $\mathrm{O}_{2}{ }^{-}$might also participate in HPD-photoinduced killing of neoplastic cells. Indeed (Fig. 2), photoirradiation of EAC cells containing HPD led to a very rapid and significant increase in the intracellular level of $\mathrm{O}_{2}^{-}$that correlated with cell death. It was also found that upon photoirradiation of EAC cells loaded with HPD, the presence of $1 \mathrm{mM} 4,5$-dihydroxy-1,3-benzene-disulfonic acid (Tiron, a cellpermeable trap of $\mathrm{O}_{2}{ }^{-}$(Watkins et al., 1999)) suppressed (by 25\%) the PDT-induced cytotoxicity that was associated with a substantial ( 2-fold) inhibition in the rate of $\mathrm{O}_{2}{ }^{-}$production (Figs. $2 \mathrm{a}$ and $\mathrm{b}$, respectively). To provide more convincing evidence the participation of $\mathrm{O}_{2}^{-}$in the phototoxic action of HPD-PDT, further experiments were performed on EAC cells pretreated with sodium diethyldithiocarbamate (DDC), an inhibitor of $\mathrm{Cu} / \mathrm{Zn}-\mathrm{SOD}$ (Heikkila et al., 1976). It is well known that cells can scavenge $\mathrm{O}_{2}{ }^{-}$with the help of this constitutive antioxidant enzyme. Studies showed that pretreatment of HPD-loaded EAC cells with DDC $(0.1 \mathrm{mM})$ caused a considerable $(\sim 60 \%)$ decrease in the activity of $\mathrm{Cu} / \mathrm{Zn}-\mathrm{SOD}$ and, as a result, a notable $(\sim 30 \%)$ increase in the rate of their HPD-photosensitized inactivation (Table 1). It is important to note that this pretreatment of EAC cells

Table 1. The influence of sodium diethyldithiocarbamate (DDC) on the phototoxicity of HPD towards EAC cells

\begin{tabular}{|c|c|c|}
\hline EAC cells ${ }^{\mathrm{a}}$ & $\begin{array}{l}\text { Activity of } \mathrm{Cu} / \mathrm{Zn}-\mathrm{SOD}, \\
\text { units/mg protein }\end{array}$ & $\begin{array}{l}\mathrm{LD}_{50} \\
\min \end{array}$ \\
\hline $\begin{array}{l}\text { Control } \\
\text { Pretreated with DDC }\end{array}$ & $\begin{array}{c}13.6 \pm 0.5 \\
5.9 \pm 0.3^{\mathrm{b}}\left(43.4 \%^{\mathrm{c}}\right)\end{array}$ & $\begin{array}{c}14.5 \pm 0.6 \\
10.8 \pm 0.5^{\mathrm{b}}\left(74.5 \%{ }^{\mathrm{c}}\right)\end{array}$ \\
\hline \multicolumn{3}{|c|}{$\begin{array}{l}\text { a }- \text { The cells were withdrawn from tumour-bearing animals, washed and loaded with HPD (at } \\
20 \mu \mathrm{g} / \mathrm{mL} \text { ). Further, the HPD-loaded cells were suspended in PBS (at a density of } 5 \times 10^{6} \text { cells } / \mathrm{mL} \text { ) } \\
\text { and incubated for } 20 \mathrm{~min} \text { in a shaking water bath at } 30^{\circ} \mathrm{C} \text { without or in the presence of } 0.1 \mathrm{mM} \\
\text { DDC. After the incubation, the control and DDT-treated cells were washed once with PBS, } \\
\text { resuspended in the same buffer at a density of } 5 \times 10^{6} \text { cells } / \mathrm{mL} \text { and illuminated with red light } \\
\text { at } 630 \mathrm{~nm} \text { under magnetic stirring at } 30^{\circ} \mathrm{C} \text {; each datum represents the mean } \pm \text { SE of } 3 \text { separate } \\
\text { experiments. } \\
\text { b- Significant difference, } P<0.01 \text {. } \\
\text { c - } \% \text { of control. }\end{array}$} \\
\hline
\end{tabular}




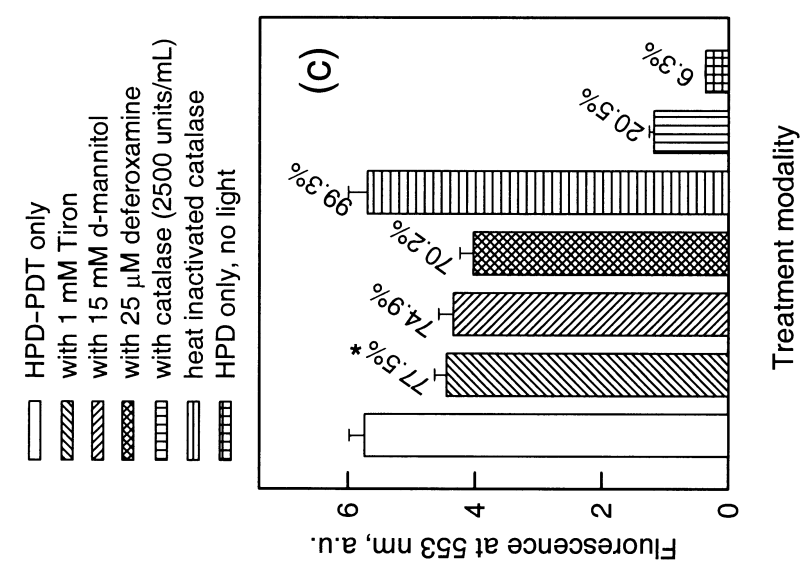

○ิ

으을

离 导

㐘

过

过节

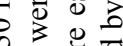

-

范证

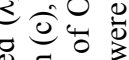

递离竞

흉흐

궁휴

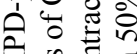

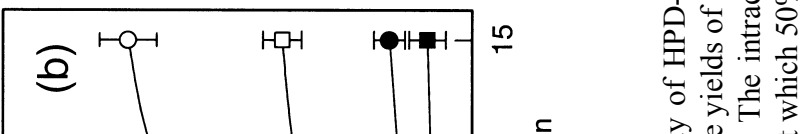

가요

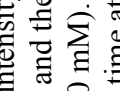

으응

ธี

范荡

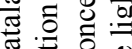

氞

吾

田

产

에 थै

輬主

है छप्ते

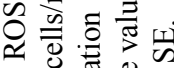

气̊․ㅡㄹ

$\times 80$

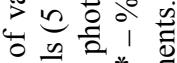

告 ${ }^{*}$

恶

论巧春

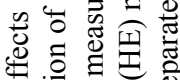

.

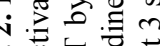

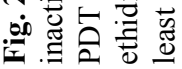


with DDC did not induce any appreciable decrease in the number of viable cells and had no effect on the activity of other antioxidant enzymes, such as CAT, GR, and GPX. Our findings are consistent with the recent data of other researchers (Golab et al., 2003), who demonstrated that SODs in tumour cells play an important role in their resistance to PDT with Photofrin ${ }^{\mathrm{TM}}$.

Further, we revealed that HPD-photosensitized inactivation of EAC cells could be mediated by the production of $\mathrm{H}_{2} \mathrm{O}_{2}$ and very reactive $\mathrm{OH}^{\circ}$. As shown in Fig. 3, photoirradiation of the cells led to the formation of significant $(\mu \mathrm{M})$ amounts of $\mathrm{H}_{2} \mathrm{O}_{2}$ and caused a substantial oxidation of DOR. It was also found that the levels of $\mathrm{H}_{2} \mathrm{O}_{2}$ and $\mathrm{OH}^{\circ}$, which were formed during photosensitization of EAC cells with HPD, are sufficient to induce cell death. Namely (Fig. 2a), the $\mathrm{LD}_{50}$ value of HPD-PDT was increased by $60 \%$ after addition of the $\mathrm{H}_{2} \mathrm{O}_{2}$-scavenging enzyme CAT ( 2500 units $/ \mathrm{mL}$ ) and by $\sim 30 \%$ in the presence of $15 \mathrm{mM}$ d-mannitol, a specific trap of $\mathrm{OH}^{\circ}$ (Goldstein \& Czapski, 1984). In addition, experiments with DOR showed that protective effects of these scavengers on the phototoxicity of HPD towards EAC cells were closely related to the suppression of $\mathrm{OH}^{\circ}$ generation (Fig. $2 \mathrm{c}$ ). The strong $(\sim 80 \%)$ inhibition of DOR breakdown by exogenously added CAT suggested that $\mathrm{H}_{2} \mathrm{O}_{2}$ is a crucial intermediate in the generation of $\mathrm{OH}^{\circ}$ and that in EAC cells subjected to HPD-PDT the radical might produce through a series of reactions called the Fenton-Haber-Weiss reaction, which consists of iron reduction by the $\mathrm{O}_{2}{ }^{\cdot}\left(\mathrm{Fe}(\mathrm{III})+\mathrm{O}_{2}{ }^{\cdot} \rightarrow \mathrm{Fe}(\mathrm{II})+\mathrm{O}_{2}\right.$ ) and subsequent $\mathrm{OH}^{\cdot}$ generation $\left(\mathrm{H}_{2} \mathrm{O}_{2}+\mathrm{Fe}(\mathrm{II}) \rightarrow \mathrm{OH}^{-}+\mathrm{OH}^{-}+\mathrm{Fe}(\mathrm{III})\right)$ (Chance et al., 1979). Further studies supported this idea. In fact (Fig. 2), we found that the $\mathrm{HPD}$-photoinduced generation of $\mathrm{OH}^{*}$ in EAC cells and, as a consequence, the efficiency of PDT were substantially decreased at the illumination of the cells in the presence of DEF, a well known chelator of iron, which can inhibit the decomposition of $\mathrm{H}_{2} \mathrm{O}_{2}$ in the Fenton-type reactions preventing thereby the formation of very cytotoxic $\mathrm{OH}^{*}$ (Stohs \& Bagchi, 1995). Control experiments showed that EAC cells are capable of producing marked amounts of $\mathrm{H}_{2} \mathrm{O}_{2}, \mathrm{O}_{2}{ }^{-}$, and $\mathrm{OH}^{*}$ radicals. However, the levels of these ROS, which were formed by the cells during their incubation in the dark or upon light exposure in the absence of HPD, were found to be considerably lesser than those after PDT (Figs. 2 and 3). The ability of mammalian cells, including transformed cells, of the generation of $\mathrm{H}_{2} \mathrm{O}_{2}$ and oxygen radicals is well documented (Szatrowski \& Nathan, 1991; Flanagan et al., 1998). At present, mitochondria are considered as one of the main sources of intracellular free radicals; it has been estimated that up to $2 \%$ of the total oxygen consumed by the mitochondrial electron transport chain undergoes one electron reduction to generate $\mathrm{O}_{2}{ }^{-\bullet}$ and subsequently other ROS such as $\mathrm{H}_{2} \mathrm{O}_{2}$ and $\mathrm{OH}^{*}$ (Chance et al., 1979).

In the present work, we found that photosensitization of EAC cells by HPD leads to the production of $\mathrm{O}_{2}{ }^{-}$, however its reactivity, like $\mathrm{H}_{2} \mathrm{O}_{2}$, is quite limited. Several ways can be envisioned in which $\mathrm{O}_{2}{ }^{-}$might transform to a more damaging species. Firstly, it was reported (Tarr \& Valenzeno, 2003) that in cells the 

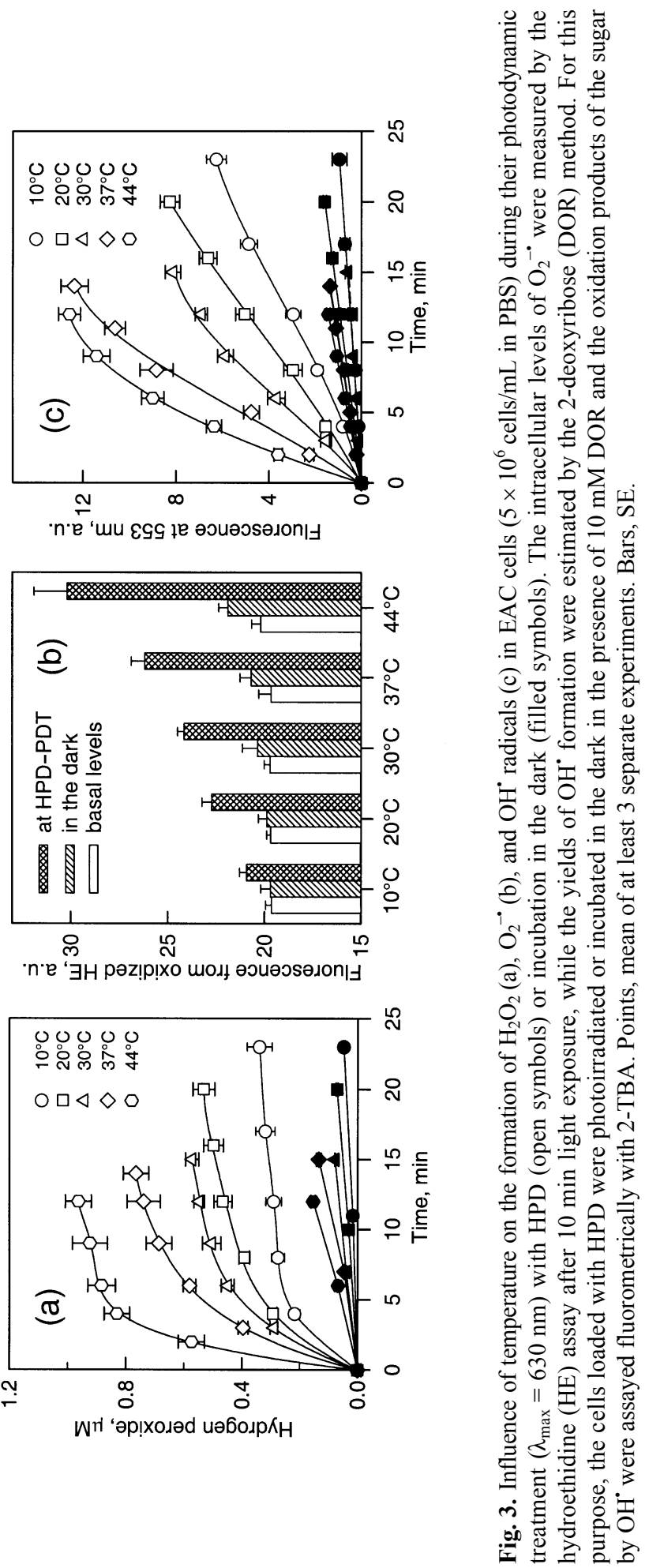
spontaneous dismutation of $\mathrm{O}_{2}{ }^{-}$can produce ${ }^{1} \mathrm{O}_{2}$, a highly reactive oxidant that is involved in the phototoxic action of HPD towards tumour cells, including EAC cells (Fig. 1). Moreover, the reaction of $\mathrm{O}_{2}{ }^{-}$with $\mathrm{H}_{2} \mathrm{O}_{2}$ can also generate ${ }^{1} \mathrm{O}_{2}$ (Mao et al., 1995). Secondly, our studies indicated that under HPD-PDT a part of the formed $\mathrm{O}_{2}{ }^{-}$could convert into $\mathrm{OH}^{*}$ that, as known, reacts at, or close to, a diffusion-controlled rate with almost all biological molecules. In fact, during photoirradiation of EAC cells loaded with HPD, the scavenging of $\mathrm{O}_{2}{ }^{-}$by Tiron $(1 \mathrm{mM})$ led to a notable $(\sim 25 \%)$ decrease in the rate of DOR oxidation, a specific trap of $\mathrm{OH}^{*}$ (Fig. 2c). There are several processes by which the photochemically generated $\mathrm{O}_{2}^{-}$could be implicated in the formation of $\mathrm{OH}^{\cdot}$ in tumour cells. It is known that $\mathrm{O}_{2}{ }^{-}$can dismutate both enzymatically and nonenzymatically into $\mathrm{H}_{2} \mathrm{O}_{2}$, a precursor of $\mathrm{OH}^{\bullet}$ in the Fenton reactions. Also, it was reported (Harris et al., 1994) that in cells $\mathrm{O}_{2}{ }^{-}$can liberate iron from storage proteins; the released iron could then participate in the Fenton-reaction-mediated production of $\mathrm{OH}^{*}$.

In this work, we demonstrated that photosensitization of tumour cells by HPD leads to the production of considerable amounts $\mathrm{H}_{2} \mathrm{O}_{2}$ and $\mathrm{O}_{2}{ }^{-}$, precursors of $\mathrm{OH}^{*}$. The generation of these ROS during PDT could be explained in two ways. The first might involve direct electron transfer from photoexcited molecules of HPD to oxygen to give $\mathrm{O}_{2}^{-}$, which after dismutation is converted into $\mathrm{H}_{2} \mathrm{O}_{2}$. The other way could be associated with HPD-sensitized photooxidation of some biomolecules, both via type 1 and 2 reactions. A comparison of the biochemical changes that were observed in PDT-treated EAC cells with the data obtained on model photodynamic systems suggested that in cells subjected to HPD-PDT the generation of $\mathrm{H}_{2} \mathrm{O}_{2}, \mathrm{O}_{2}{ }^{-}$, and $\mathrm{OH}^{*}$ could be largely attributed to the photosensitized oxidation of certain cellular constituents (such as proteins and $\mathrm{NAD}(\mathrm{P}) \mathrm{H})$ and that photoexcited HPD itself, i.e. in the absence of photooxidizable biomolecules, has poor ability to produce these ROS. Indeed, we revealed that upon photoirradiation of EAC cells loaded with HPD the formation of $\mathrm{H}_{2} \mathrm{O}_{2}, \mathrm{O}_{2}{ }^{-}$, and $\mathrm{OH}^{*}$ was associated with a serious damage of their proteins; a clearly expressed fall in the Trp content and, especially, PrSH was monitored (Figs. 3 and 4, see the results obtained at $20^{\circ} \mathrm{C}$ ). At the same time, experiments with BSA (which were performed under the same irradiation conditions) showed that in PBS similar photooxidative injuries of the model protein by HPD (at a concentration close to that in EAC cells) were also associated with the generation of sizable $(\mu \mathrm{M})$ levels of $\mathrm{H}_{2} \mathrm{O}_{2}$ and $\mathrm{O}_{2}{ }^{-}$and significant oxidation of DOR (Fig. 5). In contrast, only trace amounts of these ROS were found after photoirradiation of HPD water solutions in the absence of BSA. Besides, our studies point to the possibility that the generation of $\mathrm{H}_{2} \mathrm{O}_{2}$ and $\mathrm{O}_{2}{ }^{-}$in tumour cells could be mediated by the photoinduced oxidation $\mathrm{NAD}(\mathrm{P}) \mathrm{H}$, since upon photosensitization of EAC cells by HPD (at least in the temperature range from 20 to $30^{\circ} \mathrm{C}$ ) simultaneously with the formation of these ROS, a substantial $(\sim 30 \%)$ lowering in the intracellular content of these nucleotides was observed (data not shown). This assumption is based on the data of other researchers 


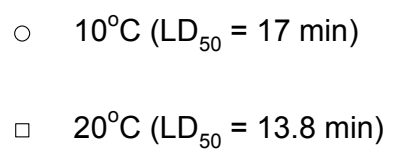

$\begin{array}{ll}\triangle & 30^{\circ} \mathrm{C}\left(\mathrm{LD}_{50}=11.8 \mathrm{~min}\right) \\ \diamond & 37^{\circ} \mathrm{C}\left(\mathrm{LD}_{50}=10.4 \mathrm{~min}\right) \\ \diamond & 44^{\circ} \mathrm{C}\left(\mathrm{LD}_{50}=8.0 \mathrm{~min}\right)\end{array}$
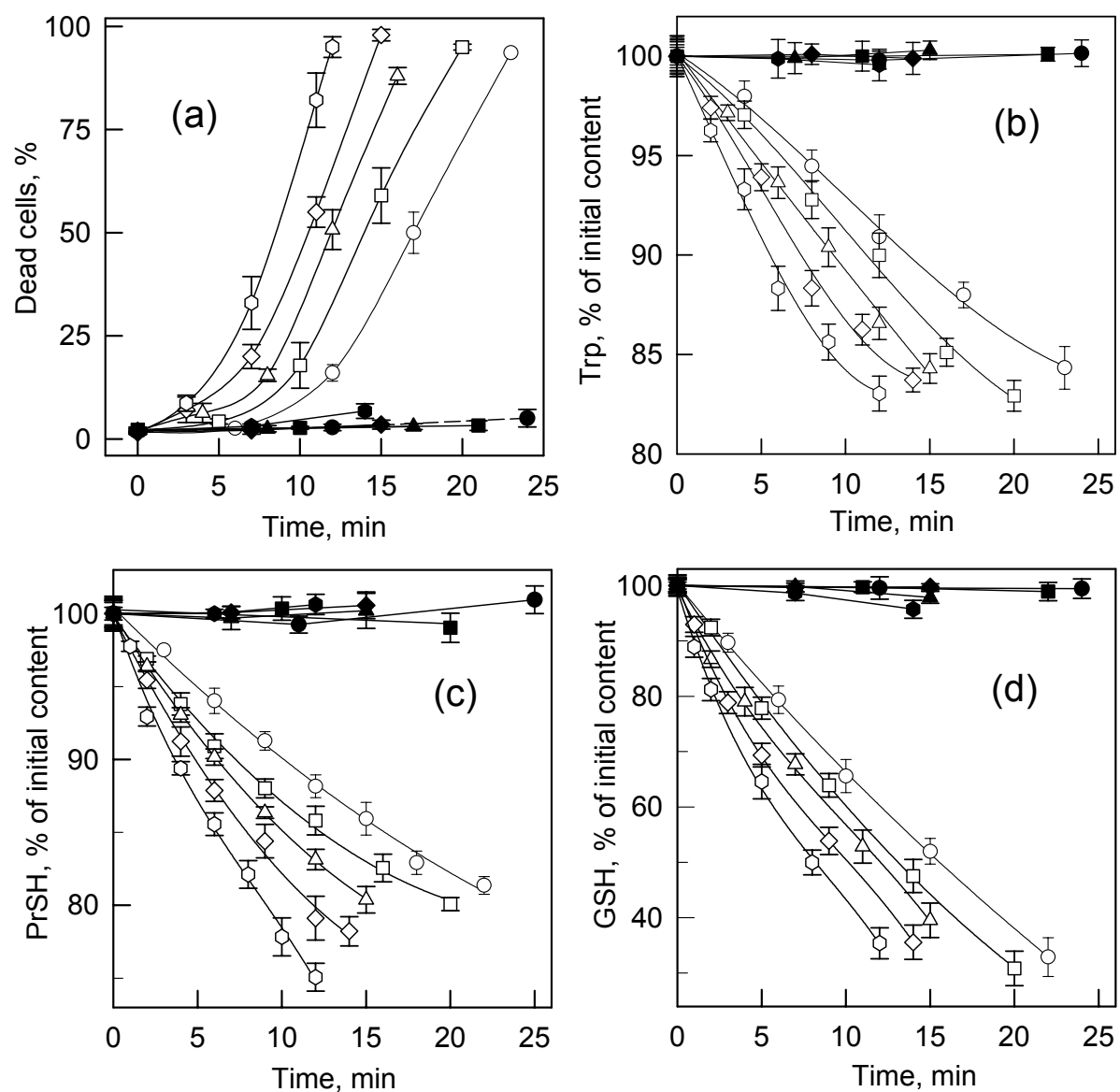

Fig. 4. Kinetics of inactivation of HPD-loaded EAC cells $\left(5 \times 10^{6}\right.$ cells $/ \mathrm{mL}$ in PBS) (a), the intracellular content of tryptophan (Trp) (b), protein-bound $\mathrm{SH}$ groups $(\mathrm{PrSH})(\mathrm{c})$, and reduced glutathione (GSH) (d) after irradiation with red light at $630 \mathrm{~nm}$ (open symbols) or during incubation in the dark at different temperatures (filled symbols). The initial levels of Trp, PrSH, and GSH in the non-irradiated cells were determined as follows (per $1 \times 10^{6}$ cells): $20.4 \pm 0.2$ nmoles for Trp, $17.05 \pm 0.68$ nmoles for PrSH, and $1.15 \pm 0.05$ nmoles for GSH. $\mathrm{LD}_{50}$ is the light exposure time at which $50 \%$ of the cells were stained by TB. All data are from 3 independent experiments. Bars, SE.

(Bodaness \& Chan, 1977; Buettner \& Hall, 1987), who discovered that HPDcatalysed photooxidation of $\mathrm{NAD}(\mathrm{P}) \mathrm{H}$ in aqueous solution leads to the generation of $\mathrm{H}_{2} \mathrm{O}_{2}$ and $\mathrm{O}_{2}^{-}$. 

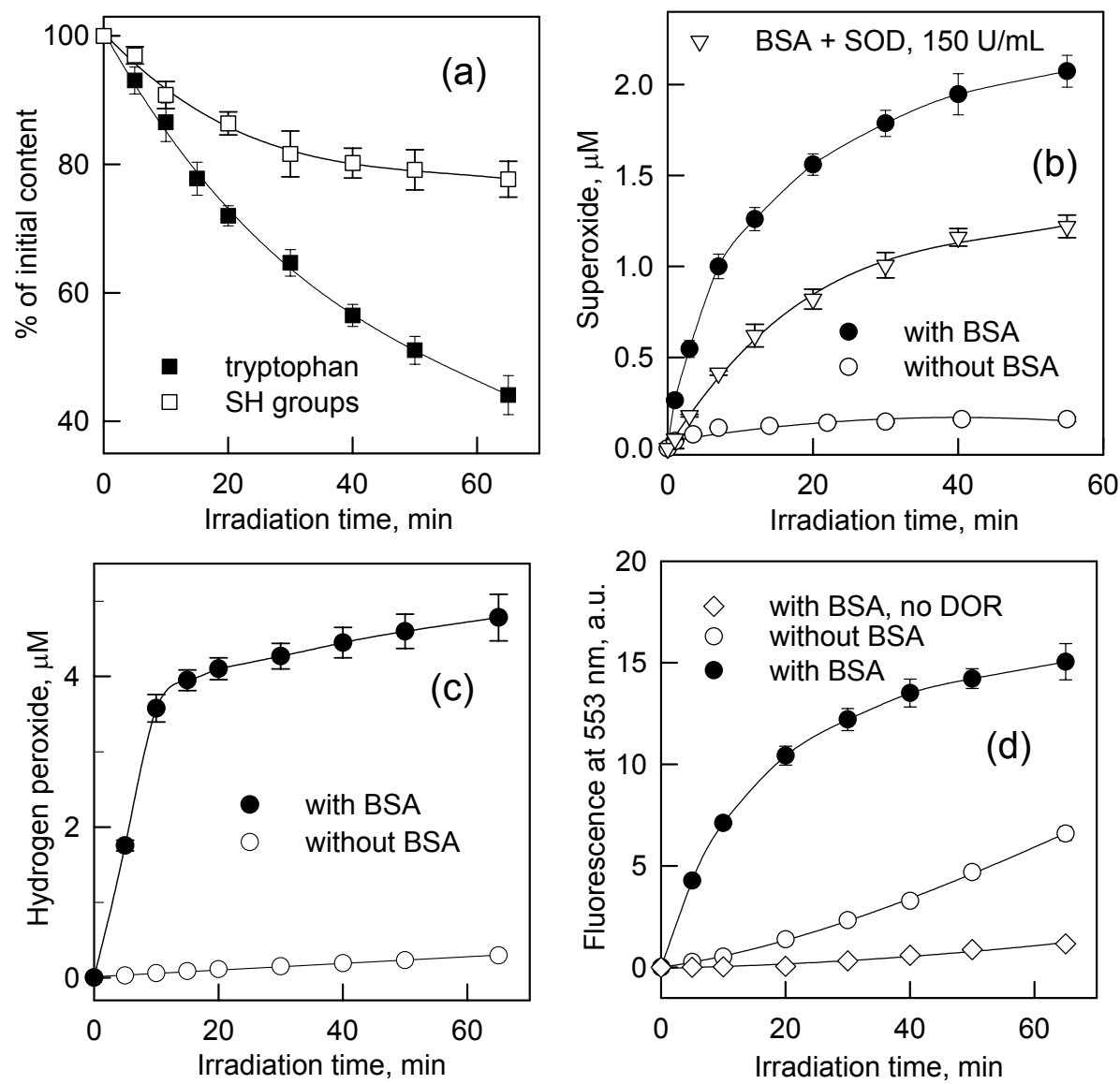

Fig. 5. Kinetics of $10 \mu \mathrm{g} / \mathrm{mL}$ HPD-photosensitized $\left(\lambda_{\max }=630 \mathrm{~nm}\right)$ degradation of bovine serum albumin (BSA, $10 \mathrm{mg} / \mathrm{mL}$ ) in PBS at $20^{\circ} \mathrm{C}$ (a) and the HPD-photoinduced generation of $\mathrm{O}_{2}^{-}$(b), production of $\mathrm{H}_{2} \mathrm{O}_{2}$ (c), and oxidation of 2-deoxyribose (DOR, $10 \mathrm{mM}$ ) (d) without or in the presence of BSA. In these experiments, the levels of $\mathrm{O}_{2}{ }^{-}$were calculated by measuring the concentration of reduced $\mathrm{NBT}$. $\mathrm{SOD}=\mathrm{Cu} / \mathrm{Zn}$ superoxide dismutase. Bars, $\mathrm{SE}$.

Thus, our studies indicated that in tumour cells subjected to HPD-PDT the production of $\mathrm{H}_{2} \mathrm{O}_{2}, \mathrm{O}_{2}^{-}$, and $\mathrm{OH}^{*}$ could be largely mediated by the porphyrinsensitized photooxidation of certain cellular constituents. Moreover, our findings suggest that in tumour cells treated with HPD-PDT the Fenton-like reactions could play an important role in the generation of $\mathrm{OH}^{\circ}$. 


\section{Studies on the role of glutathione redox cycle and CAT in the resistance of tumour cells to HPD-PDT}

In this work, we found that the phototoxic action of HPD towards tumour cells could be mediated by the production of $\mathrm{H}_{2} \mathrm{O}_{2}$. Therefore, it is of great interest to examine the importance of cellular $\mathrm{H}_{2} \mathrm{O}_{2}$-scavenging systems in the resistance of tumour cells to HPD-based PDT. A study showed that photoirradiation of EAC cells loaded with HPD induces the depletion of GSH (Fig. 4d). Namely, at light doses causing an irreversible inactivation of about $95 \%$ of the cells, a strong $(\sim 60 \%)$ decrease in the intracellular content of the antioxidant was observed. The depletion of GSH could be attributed to the known ability of thiol to direct chemical quenching of ${ }^{1} \mathrm{O}_{2}$ and other ROS (Rougee et al., 1988; Dikalov et al., 1996), and/or its oxidation by Se-dependent GPX that detoxifies $\mathrm{H}_{2} \mathrm{O}_{2}$ and lipid hydroperoxides using GSH as hydrogen donor. Taken together, this suggests that the glutathione redox cycle could play a role in the protection of tumour cells against HPD-PDT. In the work, the importance of glutathione redox cycle in the sensitivity of tumour cells to the phototoxic action of HPD was examined by disrupting the cycle at several points; by lowering the cellular stores of glutathione with BSO as well as via inhibiting the activity of GR with 1,3-bis(2-chloroethyl)-1-nitrosourea (BCNU). First, EAC cells were pretreated with BSO (in vivo) to lower the level of glutathione and their sensitivity to cytotoxicity resulting from photoexcited HPD was then estimated in vitro. As shown in Table 2, the treatment of EAC cells with BSO resulted in a substantial $(\sim 70 \%)$ decrease in the content of both GSH and total glutathione, making the cells more sensitive to the phototoxic effect of HPD; the BSO-induced depletion of glutathione caused an almost 30\% increase in the rate of EAC cells photoinactivation, as found by measuring the $\mathrm{LD}_{50}$ value of PDT. It should be pointed out that such a pretreatment of EAC cells with BSO had no effect on the cellular uptake of HPD and the number of viable cells. To provide more convincing evidence of the protective role of glutathione redox cycle, further experiments were conducted on EAC cells pretreated with BCNU (from Bristol-Myers Squibb SpA, Italy), a selective inhibitor of GR (Nathan et al., 1981); in the cycle, GR is responsible for the regeneration of GSH. The data in Table 3 indicate that pretreatment of the cells with $0.1 \mathrm{mM} \mathrm{BCNU}$ (which inhibited GR activity by $65 \%$ with no effect on the activities of GPX, CAT, or on the number of viable cells) markedly enhanced the phototoxic effect of HPD; the $\mathrm{LD}_{50}$ exposure of PDT was decreased by $22 \%$ after pretreatment of EAC cells with the inhibitor. It is important to emphasize that despite significantly decreased GR activity, GSH levels were unaffected in the cells after $25 \mathrm{~min}$ incubation with $0.1 \mathrm{mM} \mathrm{BCNU}$ at $30^{\circ} \mathrm{C}$. These results suggest that lower than normal GR activity was sufficient to maintain GSH levels. However, it was found that under HPD-PDT (at $30^{\circ} \mathrm{C}$ ) the initial rate of GSH oxidation in BCNUpretreated EAC cells $\left(2.26 \mathrm{nmoles} \mathrm{GSH} / \mathrm{min}\right.$ per $1 \times 10^{7}$ cells $)$ exceeds considerably ( $>3$-fold) that in control cells $\left(0.71 \mathrm{nmoles} \mathrm{GSH} / \mathrm{min}\right.$ per $1 \times 10^{7}$ cells $)$. This 
Table 2. The effect of D, L-buthionine-(S,R)-sulfoximine (BSO) administration on the content of glutathione in i.p. transplanted EAC cells and their sensitivity to HPD-PDT induced cytotoxicity in vitro

\begin{tabular}{c|c|c|c}
\hline EAC cells ${ }^{\mathrm{a}}$ & $\begin{array}{c}\text { Reduced glutathione, } \\
\mu \mathrm{g} \text { per } 1 \times 10^{7} \text { cells }\end{array}$ & $\begin{array}{c}\text { Total glutathione }{ }^{\mathrm{b}}, \\
\mu \mathrm{g} \text { per } 1 \times 10^{7} \text { cells }\end{array}$ & $\mathrm{LD}_{50}, \mathrm{~min}$ \\
\hline From control mice, $n=4$ & $3.74 \pm 0.16$ & $5.06 \pm 0.21$ & $12.1 \pm 0.4$ \\
From BSO-treated, $n=4$ & $1.19 \pm 0.06^{\mathrm{c}}\left(31.8 \%^{\mathrm{d}}\right)$ & $1.84 \pm 0.11^{\mathrm{c}}\left(36.4 \%^{\mathrm{d}}\right)$ & $9.5 \pm 0.3^{\mathrm{c}}\left(78.5 \%{ }^{\mathrm{d}}\right)$
\end{tabular}

a - The cells from control and BSO-treated animals (details in Materials and methods) were removed by aspiration, washed twice with PBS, and loaded with HPD (at $20 \mu \mathrm{g} / \mathrm{mL}$ ). Further, the cells were diluted with PBS (up to a density of $5 \times 10^{6}$ cells $/ \mathrm{mL}$ ) and illuminated with red light at $630 \mathrm{~nm}$ under magnetic stirring at $30^{\circ} \mathrm{C}$; each datum represents the mean $\pm \mathrm{SE}$.

$\mathrm{b}$ - Reduced + oxidized glutathione.

c - Significant difference, $P<0.02$.

d $-\%$ of control.

$n-$ Number of animals.

indicates that in the cells an inhibition of the glutathione cycle activity by BCNU enhanced the PDT-induced oxidative stress. Thus, our experiments on EAC cells clearly demonstrated that the glutathione cycle plays an important role in the protection of tumour cells against HPD-PDT induced cytotoxicity. This finding is in agreement with the data of Thomas \& Girotti (1989). Namely, using murine L1210 leukaemia cells and human CaSki cervical carcinoma cells, they showed

Table 3. Effect of 1,3-bis(2-chloroethyl)-1-nitrosourea (BCNU) on the activity of glutathione reductase in EAC cells and their sensitivity to HPD-based PDT in vitro

\begin{tabular}{|c|c|c|}
\hline EAC cells ${ }^{\mathrm{a}}$ & $\begin{array}{l}\text { Glutathione reductase activity, } \\
\text { nmoles NADPH } / \mathrm{min} / \mathrm{mg} \text { protein }\end{array}$ & $\mathrm{LD}_{50}, \min$ \\
\hline $\begin{array}{l}\text { Control } \\
\text { BCNU-treated }\end{array}$ & $\begin{array}{c}55.14 \pm 1.49 \\
19.75 \pm 0.65^{\mathrm{b}}\left(35.8 \%{ }^{\mathrm{c}}\right)\end{array}$ & $\begin{array}{c}11.0 \pm 0.33 \\
8.6 \pm 0.32^{b}\left(78.2 \%{ }^{c}\right)\end{array}$ \\
\hline \multicolumn{3}{|c|}{$\begin{array}{l}\text { a The cells were withdrawn from tumour bearing animals, washed, and loaded with HPD (at } \\
20 \mu \mathrm{g} / \mathrm{mL} \text { ). The HPD-loaded cells were then suspended in PBS (at a density of } 5 \times 10^{6} \text { cells } / \mathrm{mL} \text { ) } \\
\text { and incubated for } 25 \text { min in a shaking water bath at } 30^{\circ} \mathrm{C} \text { without or in the presence of } 0.1 \mathrm{mM} \\
\text { BCNU (dissolved in dimethyl sulfoxide, DMSO). After the incubation, the BCNU-treated and } \\
\text { control cells (instead BCNU the cells were treated with DMSO) were washed once with PBS, } \\
\text { resuspended in the same buffer at a density of } 5 \times 10^{6} \text { cells } / \mathrm{mL} \text {, and illuminated with red light at } \\
630 \mathrm{~nm} \text { under magnetic stirring at } 30^{\circ} \mathrm{C} \text {; each datum represents the mean } \pm \mathrm{SE} \text { of } 3 \text { separate } \\
\text { experiments performed in duplicate. } \\
\text { b- Significant difference, } P<0.01 \text {. } \\
\text { c } \% \text { of control. }\end{array}$} \\
\hline
\end{tabular}


that GSH and GPX play a role in the protection of the cells against the phototoxic effect of HPD that was attributed to the detoxification of the formed lipid peroxides. However, our studies suggest that protective effects of these antioxidants could be mediated by reductive decomposition of $\mathrm{H}_{2} \mathrm{O}_{2}$ that, as indicated by experiments with exogenously added CAT, is involved in the phototoxic action of the PS towards neoplastic cells (Fig. 2a).

Under PDT, tumour cells could detoxify the formed $\mathrm{H}_{2} \mathrm{O}_{2}$ not only via the glutathione cycle, but also by endogenous CAT. However, in the literature we did not find any information about the importance of CAT in the resistance of tumour cells to the phototoxic influence of HPD. To elucidate the role of the $\mathrm{H}_{2} \mathrm{O}_{2}$-scavenging enzyme, experiments were performed on EAC cells pretreated with 3-amino-1,2,4-triazole, an irreversible inhibitor of CAT (Margoliash et al., 1962). As shown in Table 4, pretreatment with aminotriazole ( $25 \mathrm{mM}$ for $1 \mathrm{~h})$ essentially (by 40\%) inhibited the activity of cellular CAT (with no effect on the activities of GPX, GR, or on the intracellular content of GSH) and markedly (by 28\%) increased the rate of HPD-photosensitized inactivation of the cells. It is important to note that preincubation of EAC cells with $25 \mathrm{mM}$ aminotriazole had a minor effect on the number of injured cells increasing it at most by $5 \%$. Thus, these experiments showed that cell-bound CAT can protect tumour cells against HPD-PDT induced cytotoxicity in vitro.

Thus, our studies on the mechanism of the action of PDT indicated that along with ${ }^{1} \mathrm{O}_{2}$ other ROS (such as $\mathrm{H}_{2} \mathrm{O}_{2}, \mathrm{O}_{2}{ }^{-}$, and $\mathrm{OH}^{*}$ ) could be involved in the HPDcatalysed photodestruction of tumour cells. Furthermore, they provided strong evidence that cellular $\mathrm{Cu} / \mathrm{Zn}-\mathrm{SOD}, \mathrm{CAT}$, and the glutathione redox cycle can protect the cells against the phototoxic action of the photodrug.

Table 4. Effect of aminotriazole (ATZ) on the activity of catalase in EAC cells and their sensitivity to HPD-photoinduced cytotoxicity in vitro

\begin{tabular}{|c|c|c|}
\hline EAC cells ${ }^{\mathrm{a}}$ & $\begin{array}{l}\text { Catalase activity, } \mu \text { moles } \\
\mathrm{H}_{2} \mathrm{O}_{2} / \text { min per mg protein }\end{array}$ & $\mathrm{LD}_{50}, \mathrm{~min}$ \\
\hline $\begin{array}{l}\text { Control } \\
\text { Pretreated with ATZ }\end{array}$ & $\begin{array}{c}9.05 \pm 0.41 \\
5.60 \pm 0.17^{\mathrm{b}}\left(61.9 \%{ }^{\mathrm{c}}\right)\end{array}$ & $\begin{array}{c}19.3 \pm 0.8 \\
15.1 \pm 0.6^{\mathrm{b}}\left(78.2 \%{ }^{\mathrm{c}}\right)\end{array}$ \\
\hline
\end{tabular}

a - The cells were withdrawn from tumour bearing animals, washed, and loaded with HPD (at $20 \mu \mathrm{g} / \mathrm{mL}$ ). The HPD-loaded cells were then suspended in Hanks' balance salt solution ( $\mathrm{pH} 7.3$ ) at a density of $5 \times 10^{6}$ cells $/ \mathrm{mL}$ and incubated for $1 \mathrm{~h}$ in a water bath at $37^{\circ} \mathrm{C}$ without or in the presence of $25 \mathrm{mM}$ ATZ. After the incubation, the control and ATZ-treated cells were washed once with PBS, resuspended in the same buffer at a density of $5 \times 10^{6}$ cells $/ \mathrm{mL}$, and illuminated with red light at $630 \mathrm{~nm}$ under magnetic stirring at $30^{\circ} \mathrm{C}$; each datum represents the mean $\pm \mathrm{SE}$ of 3 separate experiments.

b - Significant difference, $P<0.01$.

c $-\%$ of control. 


\section{The effect of temperature on the response of tumour cells to HPD-PDT}

In our studies, EAC cells loaded with HPD were irradiated with red light at $630 \mathrm{~nm}$ or incubated in the dark at five different temperatures $(10,20,30,37$, and $44^{\circ} \mathrm{C}$ ). The $30^{\circ} \mathrm{C}$ group of cells was taken as the control, as there is increasing enthusiasm (due to excellent cosmetic results) for the use of porphyrin sensitizers, including HPD, in PDT of skin cancers having the surface temperature close to $30^{\circ} \mathrm{C}$. In the work, we also assessed the sensitivity of tumour cells to the phototoxic influence of HPD at mildly hypothermic $\left(10-20^{\circ} \mathrm{C}\right)$ temperatures, because it was reported (Jones et al., 1984) that cooling of malignancies during interstitial laser photoirradiation can enhance the tumouricidal effect of PDT with HPD. Experiments showed that lowering the irradiation temperature from 30 to $10^{\circ} \mathrm{C}$ markedly (by 44\%) decreased, whereas growing the temperature from 30 to $44^{\circ} \mathrm{C}$, on the contrary, substantially (by about 1.5 -fold) increased the rate of HPD-photosensitized inactivation of EAC cells, as found by measuring the $\mathrm{LD}_{50}$ value of PDT (Fig. 4a). However, incubation of the cells in the dark, irrespective of temperature conditions, did not induce any noticeable increase in the number of injured cells. As cellular proteins are the target for HPD-PDT as well as for heat inactivation (Hildebrandt et al., 2002), we examined the influence of temperature on HPD-photoinduced damage of proteins in EAC cells; in one of our prior studies we already demonstrated that under HPD-PDT the cells die mainly via photooxidative injuries of their proteins (Shevchuk et al., 2002). As shown in Fig. 4, the photodynamic treatment of EAC cells by HPD led to a substantial modification of the amino acid composition of their proteins; namely, the part of photooxidized amino acid residues after $15 \mathrm{~min}$ illumination at $30^{\circ} \mathrm{C}$ that caused an irreversible inactivation of $\sim 90 \%$ of the cells, was determined as $15 \%$ for Trp and $20 \%$ for PrSH. It was found that sub- $\left(37^{\circ} \mathrm{C}\right)$ and hyperthermic $\left(44^{\circ} \mathrm{C}\right)$ heating accelerated the HPD-catalysed photoinjury of proteins in EAC cells. Namely, upon raising the temperature from 30 to $44^{\circ} \mathrm{C}$ a substantial ( $\left.~ 55 \%\right)$ growth in the rates of Trp residues and $\mathrm{PrSH}$ photooxidation was registered that well correlated with the increase in the rate of HPD-PDT induced inactivation of the cells. On the contrary, lowering the irradiation temperature from 30 to $10^{\circ} \mathrm{C}$ made cell proteins less sensitive to the photooxidative injuries resulting in the protection of the cells against HPD-PDT induced cytotoxicity. However, neither heat shock nor cold stress itself induced similar changes in the amino acid composition of cell proteins.

Further, we evaluated the influence of heat shock on the oxidative potency of PDT with HPD, using GSH as a biomarker of oxidative stress. Studies showed that heating enhances the HPD-PDT-induced oxidative stress in tumour cells. Indeed, we revealed that EAC cells subjected to HPD-PDT at 37 and $44{ }^{\circ} \mathrm{C}$ had lower levels of GSH as compared with the control cells treated by the PDT at $30^{\circ} \mathrm{C}$ (Fig. 4d). It is important to note that incubation of the cells in the dark even at a hyperthermic $\left(44^{\circ} \mathrm{C}\right)$ temperature caused only a minor $(\sim 5 \%)$ decrease in the intracellular content of GSH. On the contrary, a shift in the temperature from 
30 to $10^{\circ} \mathrm{C}$ led a substantial ( $\left.40 \%\right)$ decrease in the rate of HPD-photoinduced oxidation of GSH in the cells. This indicates that cooling suppressed the PDT induced oxidative stress in EAC cells.

Thus, our in vitro experiments clearly indicated that heating intensifies the HPD-PDT-induced oxidative stress in tumour cells, promotes the photooxidative damage of proteins in the cells, and increases in a synergistic manner their susceptibility to the cytotoxicity resulting from photoexcited HPD, while hypothermia (cooling up to $10^{\circ} \mathrm{C}$ ) inhibits the phototoxic action of the PS. A remarkable observation of the study is also that the potentiating effect of heating on HPDphotosensitized killing of tumour cells may take place at $37^{\circ} \mathrm{C}$, i.e. at temperatures below hyperthermic. This observation is consistent with the results of other researchers (Orenstein et al., 1999).

\section{On the generation of ROS in tumour cells during HPD-PDT at elevated temperatures}

In these studies, we concentrated our efforts on the elucidation of the mechanism of pro-oxidative effects of heat stress in PDT with HPD, because this permits to explain an increased sensitivity of tumour cells to the phototoxic influence of the drug at elevated temperatures. First, we tested the possibility that heating could induce the disaggregation of HPD components in tumour cells, as the event must, in turn, lead to an increased production of extremely cytotoxic ${ }^{1} \mathrm{O}_{2}$. Our model experiments supported the assumption. The proportion of monomeric and aggregated moieties of HPD can be evaluated by measuring the fluorescence intensity of its solutions that decreases in the aggregated state (Pottier \& Truscott, 1986). Figure 6 depicts the changes in the fluorescence spectrum of non-illuminated HPD in cell free PBS depending on the temperature. Analysis of the spectral changes showed that heating of HPD induces an increase in the portion of its monomeric species in the buffer, because upon raising the temperature from 10 to $44^{\circ} \mathrm{C}$ a notable $(\sim 30 \%)$ increase in the fluorescence intensity of HPD solutions was observed (Fig. 6). Moreover, we found that in PBS a rise in the temperature from 10 to $44^{\circ} \mathrm{C}$ caused a 2.4 -fold increase in the rate of $10 \mu \mathrm{g} / \mathrm{mL}$ HPD-photosensitized oxidation of $0.2 \mathrm{mM}$ Trp that is mediated by ${ }^{1} \mathrm{O}_{2}$ and could be ascribed partly to higher yields of the oxidant formation (Moan, 1984). Further studies performed on HPD-loaded EAC cells showed that the PS, contrary to its aqueous solutions, became more aggregated when the cells were heated in a water bath. As illustrated in Fig. 7, the heating of EAC cells from 10 to $44^{\circ} \mathrm{C}$ resulted in a $25 \%$ fall in the fluorescence intensities of HPD in the cells without any shifts in the position of its main fluorescence peaks at 630 and $677 \mathrm{~nm}$. Microscopical studies showed that this event could be attributed to a heat-induced shortening in the cell volume; upon rising the temperature from 10 to $44^{\circ} \mathrm{C}$ a substantial (1.5-2-fold) decrease in the volume of EAC cells was registered. Thus, we cannot explain the potentiating action of photoirradiation-induced heating on the antitumour efficiency of HPD-PDT via an enhancement in the formation of ${ }^{1} \mathrm{O}_{2}$ due to disruption of self-aggregated moieties of the PS. 


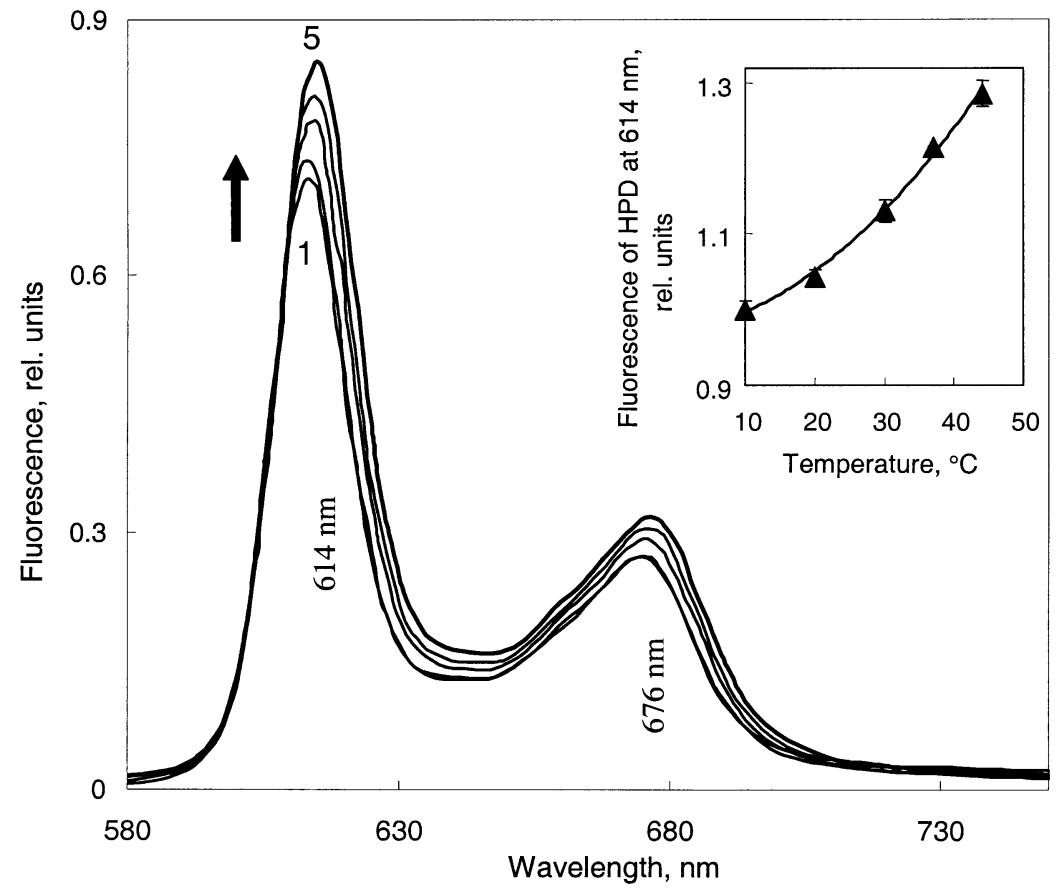

Fig. 6. Fluorescence emission spectra of HPD $(10 \mu \mathrm{g} / \mathrm{mL})$ dissolved in PBS at various temperatures $\left(\lambda_{\mathrm{ex}}=500 \mathrm{~nm}\right.$; sample light path, $\left.1 \mathrm{~cm}\right)$. Spectra from 1 to 5 represent temperatures of $10,20,30,37$, and $44^{\circ} \mathrm{C}$, respectively. Inset: fluorescence intensities of the HPD solutions at $614 \mathrm{~nm}$ as a function of temperature.

Heat stress during PDT could promote the HPD-induced photooxidative damage of cellular constituents and, as a consequence, tumour cell eradication via an increase in the reactivity of ${ }^{1} \mathrm{O}_{2}$ (Gottfried \& Kimel, 1991) as well as through the simulation of other ROS formation. In fact, we found that upon HPD-PDT a rise in the temperature from 30 to $44^{\circ} \mathrm{C}$ strongly enhanced the production of $\mathrm{H}_{2} \mathrm{O}_{2}, \mathrm{O}_{2}{ }^{-}$, and $\mathrm{OH}^{*}$ in EAC cells that directly correlated with an increase in the rate of HPD-photoinduced inactivation of the cells (Figs. 3 and 4, respectively). On the contrary, lowering the irradiation temperature from 30 to $10^{\circ} \mathrm{C}$ led to a significant inhibition of the formation of these ROS in EAC cells and, as a result, to a decrease in the efficiency of PDT with HPD. In this work, we did not examine the mechanism of the heat-induced activation of $\mathrm{H}_{2} \mathrm{O}_{2}$ and oxygen radicals formation upon photosensitization of EAC cells with HPD; however, the event could be attributed to the stimulatory effects of heating on primary photophysical processes as well as on the photooxidation of certain cell constituents (e.g. proteins, see the data presented in Figs. 4 and 5) by photoexcited molecules of the porphyrin, both via Type 1 and 2 photochemistry. In addition, our investigations showed that heat stress itself promotes the generation of ROS in tumour cells. In fact, raising the temperature from 30 to $44^{\circ} \mathrm{C}$ caused a marked increase in the rates of $\mathrm{H}_{2} \mathrm{O}_{2}$, 


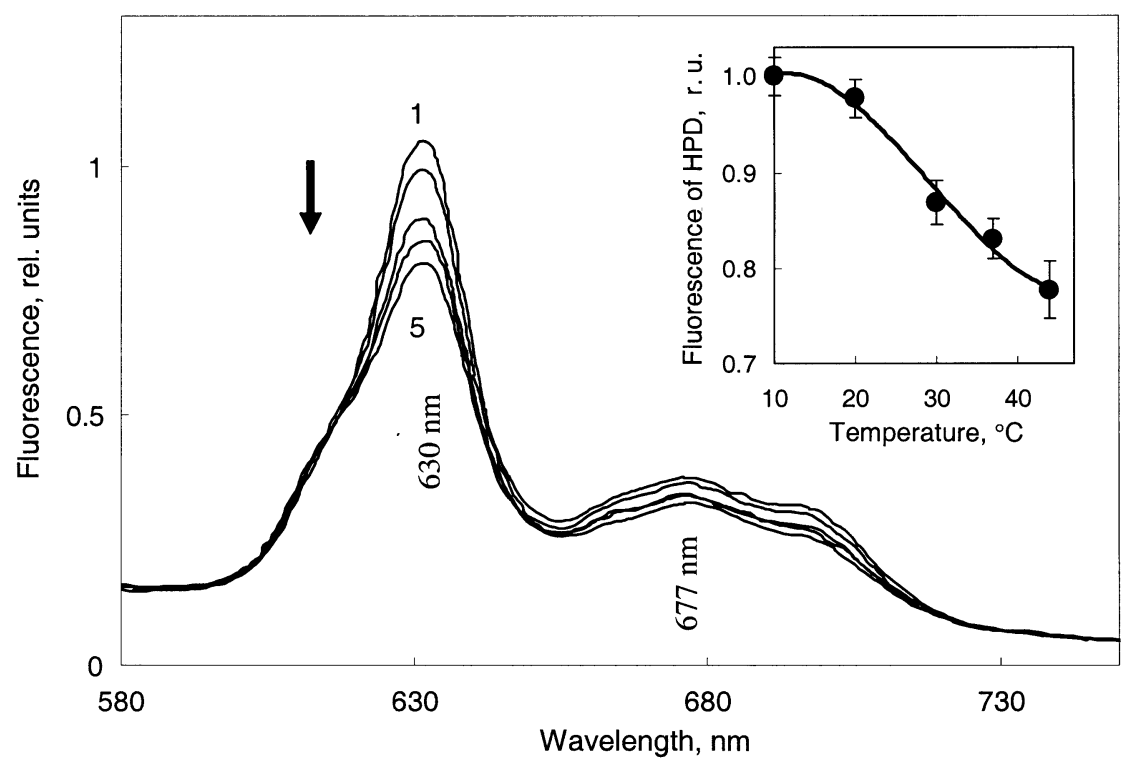

Fig. 7. Fluorescence emission spectra of HPD $\left(\lambda_{\mathrm{ex}}=505 \mathrm{~nm}\right)$ in EAC cells $\left(5 \times 10^{6}\right.$ cells $/ \mathrm{mL}$ in PBS) at different temperatures (sample light path, $1 \mathrm{~cm}$ ). Spectra from 1 to 5 represent temperatures of $10,20,30,37$, and $44^{\circ} \mathrm{C}$, respectively. Inset: fluorescence intensities of HPD in the cells at $630 \mathrm{~nm}$ as a function of temperature. Before the spectroscopic measurements, EAC cells loaded with HPD were placed in a water bath and incubated in the dark at a desired temperature for 5 min.

$\mathrm{O}_{2}{ }^{-}$, and $\mathrm{OH}^{\bullet}$ production by non-irradiated EAC cells (Fig. 3). The finding is in a good agreement with the observations of other researchers (e.g. Flanagan et al., 1998), who discovered that heating (from 37 to $43-45^{\circ} \mathrm{C}$ ) of non-transformed as well as tumour cells strongly enhances the generation of oxygen radicals in the cells. Until now, the precise location and mechanisms of increased formation oxygen-derived free radicals during heat stress remain unclear. Nevertheless, there are some indications that the mitochondrial electron transport chain could be responsible for an increased production of $\mathrm{O}_{2}{ }^{-}$and $\mathrm{H}_{2} \mathrm{O}_{2}$ (precursors of $\mathrm{OH}^{*}$ ) in cells subjected to a thermal stress (Salo et al., 1991). Our data are consistent with these findings; it was found that within the temperature range of $10-44{ }^{\circ} \mathrm{C}$, the ability of EAC to produce $\mathrm{H}_{2} \mathrm{O}_{2}$ is directly related to the respiratory activity of the cells (Fig. 8). It was suggested that the cellular damage and/or toxicity associated with hyperthermia could be mediated in part by an increased flux of oxygen-free radicals (e.g. Li \& Oberley, 1997). On this basis, we believe that heat shock during HPD-PDT can enhance the generation of ROS by tumour cells, which along with photochemically generated oxidants could take part in the therapy-induced eradication of diseased tissues. Thus, our studies on the mechanism of the potentiating effect of light-induced heating on the antitumour efficiency of PDT with HPD suggest that the phenomenon could be explained via heat-induced increases in the formation of cytotoxic ROS, such as $\mathrm{H}_{2} \mathrm{O}_{2}, \mathrm{O}_{2}{ }^{-}$, and 


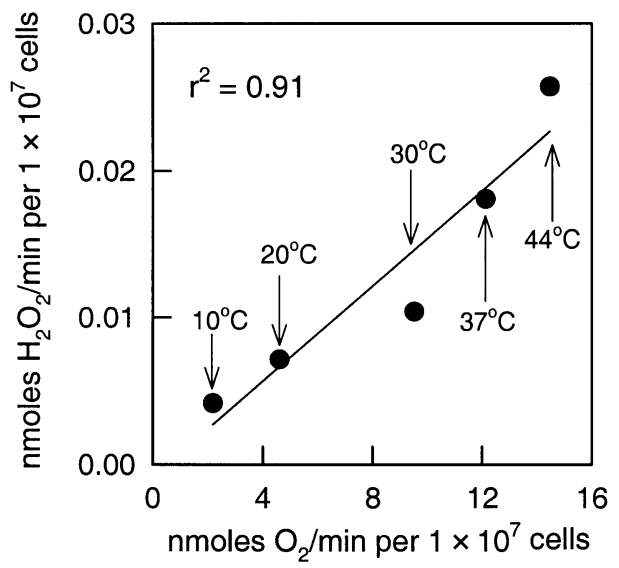

Fig. 8. The interrelationship between the rate of $\mathrm{H}_{2} \mathrm{O}_{2}$ production by non-illuminated EAC cells and their respiratory activity at various temperatures.

$\mathrm{OH}^{*}$. Moreover, the heating during PDT could promote the HPD-mediated photodestruction of tumour cells not only by increasing generation, but also reactivity of oxygen radicals (Issels et al., 1986). It was also reported that hyperthermia $\left(42^{\circ} \mathrm{C}\right)$ can enhance the cytotoxicity of $\mathrm{H}_{2} \mathrm{O}_{2}$ (Lord-Fontaine \& Averill, 1999).

\section{Effects of hyperthermia alone or jointly with $\mathrm{HPD}-\mathrm{PDT}$ on $\mathrm{H}_{2} \mathrm{O}_{2}$-detoxifying systems of tumour cells}

Heat shock during HPD-PDT could promote an increase in oxidative stress and thereby enhance the tumour response to the therapy by inactivating cellular antioxidant defences. In this connection, we investigated the intactness of CAT and the glutathione redox cycle in EAC cells during their incubation in the dark as well as upon HPD-PDT at elevated temperatures. In the work, we already demonstrated that the $\mathrm{H}_{2} \mathrm{O}_{2}$-detoxifying systems play an important role in the protection of the cells against the phototoxic action of HPD (Tables 2, 3, and 4). This research trend presents substantial interest, since in the literature there is only limited information on the influence of hyperthermia and HPD-photosensitized reactions on the activity of CAT or enzymes of the glutathione cycle in transformed cells. We found that hyperthermia $\left(44^{\circ} \mathrm{C}\right)$ itself had a minor effect on the levels of GSH in EAC cells and did not induce any noticeable decrease in the activity of cellular GPX. However, further studies revealed that the $\mathrm{H}_{2} \mathrm{O}_{2}$-destroying enzyme was inactivated during photosensitization of EAC cells with HPD and that heating promoted the photoinduced degradation of GPX in the cells. In fact, the photoirradiation of HPD-loaded EAC cells at the control temperature $\left(30^{\circ} \mathrm{C}\right)$ caused a $30 \%$ decrease in the GPX activity, and upon elevating the temperature to $44^{\circ} \mathrm{C}$, a strong ( $\sim 2$-fold) increase in the rate of the enzyme inactivation was observed (Fig. 9a). In contrast, lowering the temperature from 30 to $10^{\circ} \mathrm{C}$ protected GPX 

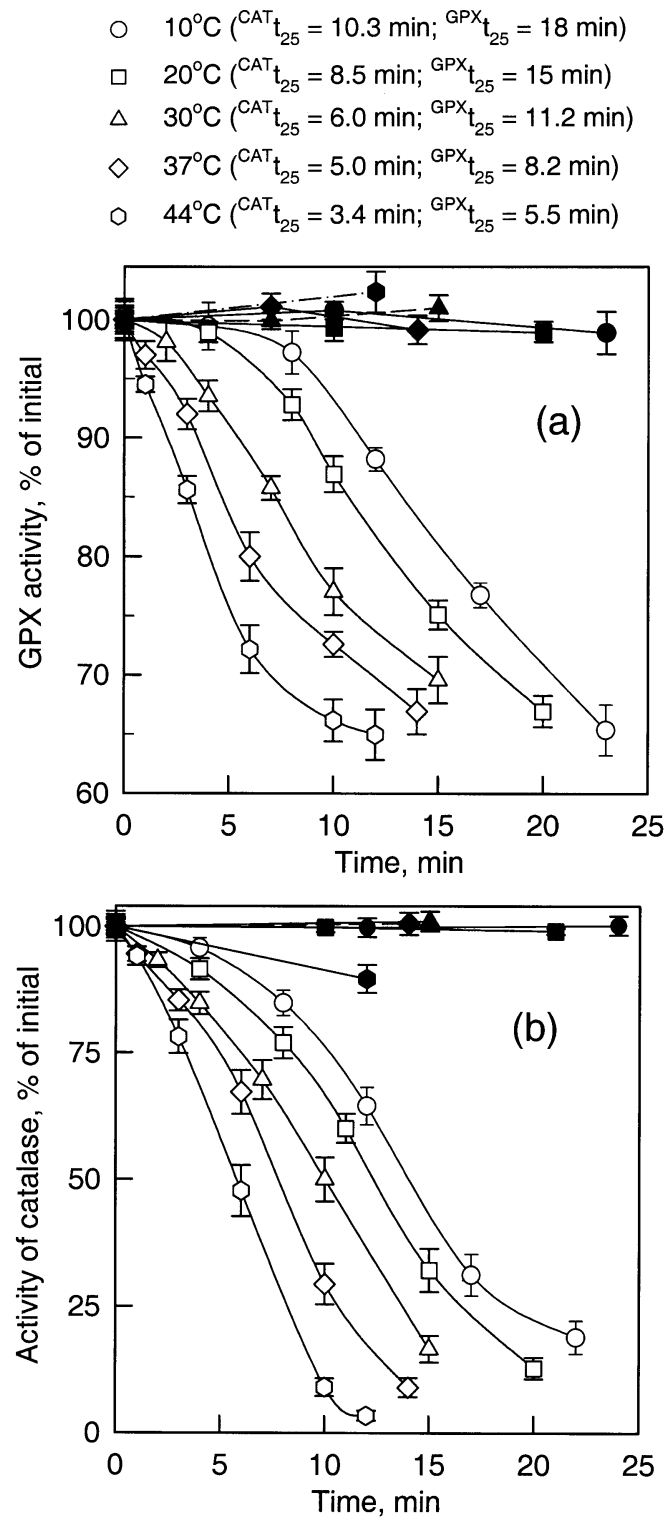

Fig. 9. The activity of glutathione peroxidase (GPX) (a) and catalase (b) in HPD-loaded EAC cells $\left(5 \times 10^{6}\right.$ cells $/ \mathrm{mL}$ in PBS) after their irradiation with red light at $630 \mathrm{~nm}$ (open symbols) or incubation in the dark at various temperatures (filled symbols). The initial activities of catalase and GPX in the cells were determined as $9.46 \pm 0.41 \mu$ moles $\mathrm{H}_{2} \mathrm{O}_{2}$ decomposed/min per mg protein and $49.3 \pm 2.1$ nmoles NADPH oxidized/min per mg protein, respectively. ${ }^{C A T} t_{25}$ and ${ }^{\mathrm{GPX}} \mathrm{t}_{25}$ are the light doses at which $25 \%$ inhibition in the activity of catalase and GPX was observed; in this work, the parameters were used to estimate the efficiency of HPD-mediated photoinactivation of the $\mathrm{H}_{2} \mathrm{O}_{2}$ detoxifiyng enzymes. The points with error bars refer to 3 independent experiments. 
against HPD-photoinduced inactivation. Similar results were obtained during a study of the effects of hyperthermia alone or jointly with HPD-PDT on the activity of CAT in EAC cells. It was found that like GPX, the $\mathrm{H}_{2} \mathrm{O}_{2}$-detoxifying enzyme was inactivated during photoirradiation of HPD-loaded EAC cells and that heating sensitized CAT to HPD-photoinduced inactivation. Namely (Fig. 9b), raising the temperature from 30 to $44^{\circ} \mathrm{C}$ resulted in a considerable $(\sim 2$-fold) increase in the rate of HPD-PDT mediated inactivation of CAT in the cells. Moreover, experiments showed that in EAC cells CAT, in comparison with GPX, is much more sensitive to the inactivating influence of HPD-PDT or heat treatment. Indeed (Fig. 9), at light doses that caused an irreversible inactivation of about $90 \%$ of the cells only a small $(\sim 30 \%)$ fall in the activity of GPX took place, while the activity of cellular CAT was inhibited by almost $95 \%$. It was also established that hyperthermia, a 12 min incubation of EAC cells in the dark at $44^{\circ} \mathrm{C}$, caused a marked $(\sim 10 \%)$ decrease in the activity of cellular CAT, whereas after the same incubation the activity of GPX in the cells remained practically unchanged. Thus, our studies suggest that under PDT the HPD-mediated photoinactivation of cellbound GPX and CAT could result in loss of protection against accumulating $\mathrm{H}_{2} \mathrm{O}_{2}$, providing an additional pathway of phototoxicity. In addition, they suggest that upon PDT with HPD the heating associated with the absorption of optical radiation may promote the phototherapy-induced oxidative stress and, as a consequence, the tumour eradication via increasing the rates of HPD-photosensitized inactivation of cellular CAT and GPX.

\section{The effect of temperature on photochemical transformations of HPD in tumour cells}

In this series of our studies, we examined the effect of heating on the photochemical transformations of HPD (its degradation as well as PhP-640 formation) in tumour cells, since these aspects of PDT remain undetermined. At the same time, this information could clarify some discordance in the literature data concerning the influence of temperature on the antitumour efficiency of PDT with the PS. For the most part, studies on the mechanism of HPD-PDT suggest that heating associated with photoirradiation enhances the tumouricidal action of the phototherapy (e.g. Leunig et al., 1994). However, it was reported (Jones et al., 1984) that the cooling of tumours during interstitial phototherapy with HPD also improves the tumour response to the photochemotherapy indicating that a PDT-associated heating of tumours may reduce the treatment efficiency. One possible explanation for the phenomenon might be that the lowering of the temperature of tumour tissues during light exposure inhibits the photodecay of HPD in these tissues and, as a consequence, results in an increased yield of inactivation of tumour cells per incident photon. In this connection, we examined the influence of temperature on photostability of HPD in tumour cells. Experiments on EAC cells loaded with HPD showed that the PS is progressively destroyed during illumination and that the rate of HPD photobleaching in the cells depends largely on the temperature of a medium. Namely (Fig. 10a), we found that elevating the temperature from 30 to $44{ }^{\circ} \mathrm{C}$ resulted in a considerable ( 3 -fold) increase in the rate of HPD 
photodecay in EAC cells, whereas the cooling of the cells from 30 to $10^{\circ} \mathrm{C}$ caused a substantial (more than 4-fold) inhibition in the rate of the sensitizer photodegradation (as found by measuring a slope on the kinetic curves of HPD photobleaching). It is important to note that independently of temperature conditions, a prolonged (20-25 min) incubation of EAC cells in the dark did not induce any marked lowering in the initial content of HPD in the cells. At the same time, experiments showed HPD to be a relatively photostabile drug. Indeed (Fig. 10a),
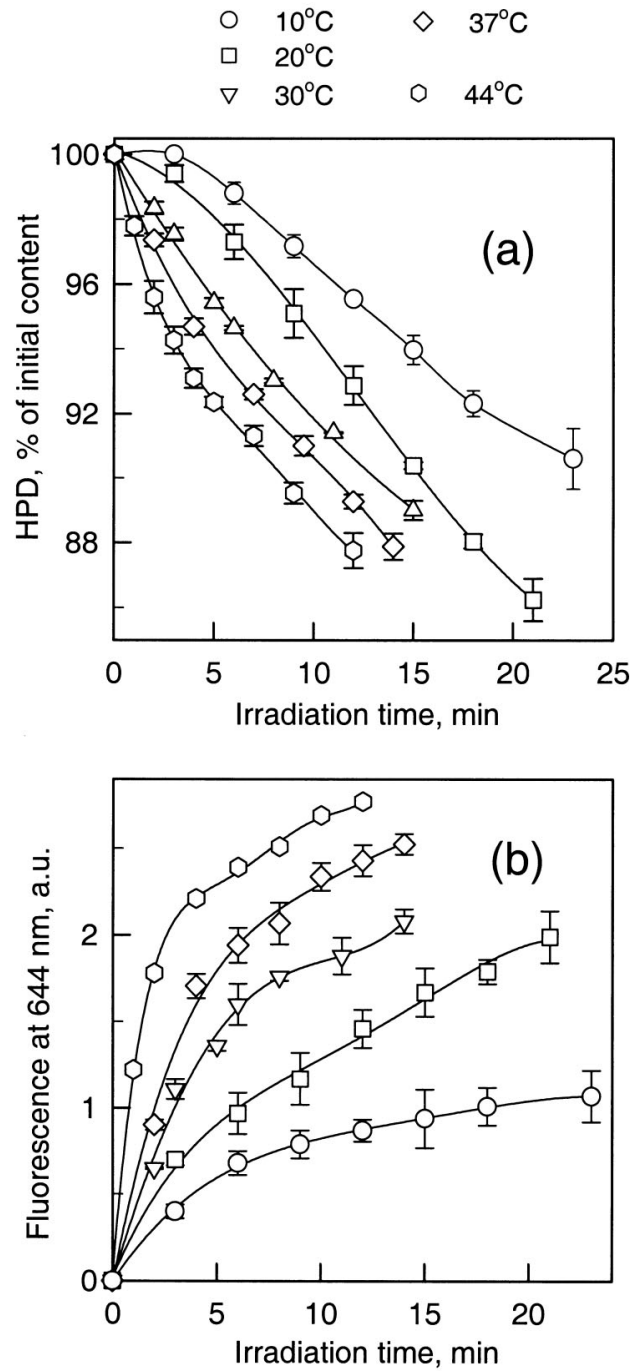

Fig. 10. Kinetics of HPD photodegradation (a) and photoproduct-640 formation (b) in EAC cells $\left(5 \times 10^{6}\right.$ cells $/ \mathrm{mL}$ in PBS $)$ during their irradiation $\left(\lambda_{\max }=630 \mathrm{~nm}\right)$ at different temperatures. The initial content of HPD in the cells was determined as $77.7 \pm 5.3 \mathrm{ng}$ per $1 \times 10^{6}$ cells. Points, mean of at least 3 separate experiments. Bars, SE. 
at a normal $\left(30^{\circ} \mathrm{C}\right)$ temperature and at the light dose causing an irreversible inactivation of about $95 \%$ of the cells, only a small $(\sim 11 \%)$ decrease in the intracellular level of HPD took place. Furthermore, at the light doses causing a $95 \%$ decrease in the number of viable cells, the yield of HPD photobleaching in EAC cells was changed only slightly (at the most by $2 \%$ ) upon heating (to $44^{\circ} \mathrm{C}$ ) or cooling the cells to $10^{\circ} \mathrm{C}$. Thus, although the rate of HPD photobleaching in tumour cells is found to be largely dependent on the temperature, our data suggest the very low probability (due to high photostability of HPD) that at a sufficient concentration of the PS in tumour tissues the efficiency of PDT could be appreciably affected by a stimulatory influence of sub- or hyperthermic temperatures on the photobleaching of HPD in malignancies. Hence, most likely other causes underlie the potentiating effect of cooling on the antitumour efficiency of interstitial PDT with HPD.

In the further experiments, we tested the hypothesis that the potentiating influence of light-induced heating on HPD-PDT-induced tumour eradication could be mediated by a heat-catalysed increase in the formation of PhP-640, since it was suggested that accumulation of the chlorin-type photoproduct can cause an increase in the absorption in the red spectral region at around 620-650 $\mathrm{nm}$ during illumination of tumours in vivo and that it possesses photosensitizing activity (Giniunas et al., 1991). In other words, the light sources used in PDT must effectively excite not only HPD but also the PhP-640, because the absorption band of the photoproduct is not significantly red shifted (Rotomskis et al., 1996). Using fluorescence spectroscopy, we found that photoirradiation of HPD-loaded EAC cells resulted in a very rapid and substantial growth in the intracellular level of the red-absorbing photoproduct and that its formation in the cells exhibited a strong tendency to increase with increasing temperature (Fig. 10b). Namely, upon elevating the temperature from 30 to $44^{\circ} \mathrm{C}$ a considerable ( $>3$ times) increase in the rate of PhP-640 formation was observed (the energy activation of the photoproduct formation was calculated as $42.3 \pm 2.9 \mathrm{~kJ} / \mathrm{mole})$. It must be noted that a prolonged (25 min) incubation of HPD-loaded EAC in the dark even at a hyperthermic $\left(44^{\circ} \mathrm{C}\right)$ temperature did not generate any detectable levels of the chlorin-type compound. Thus, these findings speak in favour of our hypothesis that the potentiating effect of photoirradiation-induced heating on the efficiency of HPD-PDT could be mediated, in part, by an increased generation of PhP-640.

In this work, an attempt was also made to estimate the significance of PhP-640 in the phototoxic action of HPD against tumour cells at elevated temperatures. For this purpose, a heat-induced increase in the phototoxic action of HPD towards EAC cells after their irradiation with red light at $630 \mathrm{~nm}$ (which can excite both HPD and PhP-640) was compared with that at $510 \mathrm{~nm}$ (which cannot excite $\mathrm{PhP}-640$, since the photoproduct does not absorb appreciably in this spectral region (Rotomskis et al., 1996)). It was found that the potentiating influence of a thermal stress on HPD-photosensitized inactivation of EAC cells was less effective when the cells were irradiated with green light at $510 \mathrm{~nm}$ as compared with that at $630 \mathrm{~nm}$. In fact (Table 5), under the PDT with red light at $630 \mathrm{~nm}$ a shift in the 
Table 5. Influence of temperature on the efficiency of HPD-sensitized photooxidation of tryptophan (Trp) in aqueous solution and photoinactivation of EAC in vitro depending on the wavelength of incident light

\begin{tabular}{|c|c|c|}
\hline Irradiation conditions & $\begin{array}{l}\text { Rates of Trp oxidation } \\
\mu \mathrm{M} \min ^{-1} \pm \mathrm{SE}(n=3)\end{array}$ & $\mathrm{LD}_{50}, \min \pm \mathrm{SE}(n=3)$ \\
\hline $30^{\circ} \mathrm{C}, \lambda_{\max }=510 \mathrm{~nm}$ & $6.74 \pm 0.22$ & $7.7 \pm 0.4$ \\
\hline $44^{\circ} \mathrm{C}, \lambda_{\max }=510 \mathrm{~nm}$ & $9.95 \pm 0.31\left(147.6 \%^{\mathrm{b}}\right)$ & $6.1 \pm 0.3^{c}\left(79.2 \%^{b}\right)$ \\
\hline $30^{\circ} \mathrm{C}, \lambda_{\max }=630 \mathrm{~nm}$ & $1.81 \pm 0.05$ & $13.8 \pm 0.5$ \\
\hline $44^{\circ} \mathrm{C}, \lambda_{\max }=630 \mathrm{~nm}$ & $3.02 \pm 0.09\left(166.9 \%^{\mathrm{b}}\right)$ & $8.9 \pm 0.3^{c}\left(64.5 \%{ }^{b}\right)$ \\
\hline
\end{tabular}

irradiation temperature from 30 to $44^{\circ} \mathrm{C}$ caused a $55 \%$ increase in the rate of HPD-photoinduced eradication of EAC cells, but a substantially lesser (by 26\%) growth in the rate was observed when the cells were exposed to green light at $510 \mathrm{~nm}$.

It was reported (Karu, 1999) that visible light itself, i.e. in the absence of exogenously added photosensitizing agents, can cause serious changes in cellular homeostasis parameters (a shift in the redox state of mitochondria, cellular $\mathrm{pH}$, the level of adenosine triphosphate, $\mathrm{Ca}^{2+}$, etc.) and that these light-induced alterations in cellular homeostasis are largely dependent on the wavelength of radiation. Hence, it could be assumed that under HPD-PDT the irradiation of EAC cells with red light at $630 \mathrm{~nm}$ caused, as opposed to green light at $510 \mathrm{~nm}$, such a change in cell homeostasis that made the cells more vulnerable to a thermal stress. To discard this possibility and to obtain more convincing evidence the possible contribution of $\mathrm{PhP}-640$ to a heat-mediated increase in the tumouricidal effect of HPD-PDT in vivo, we examined the influence of heating on the formation of PhP-640 as well as the temperature dependence of photosensitising activity of HPD on the wavelength of radiation using the simplest photochemical system Trp and HPD dissolved in PBS. It was found that when the system was exposed to red light at $630 \mathrm{~nm}$, raising the temperature from 30 to $44^{\circ} \mathrm{C}$ led to a considerable $(67 \%)$ increase in the rate of HPD-sensitized photooxidation of Trp, which correlated well with a heat-induced increase in the rate of PhP-640 formation (Table 5 and Fig. 11, respectively). However, the same heating of a reaction mixture produced a markedly smaller (by $47.6 \%$ ) increase in the rate of HPD-photoinduced oxidation of Trp if the mixture was irradiated with green light at $510 \mathrm{~nm}$ that, as mentioned above, cannot excite the PhP-640 (Table 5). Thus, our findings strongly suggest that during clinical PDT employing a $630 \mathrm{~nm}$ laser light to activate HPD, an increase in the temperature of tumour tissues associated with the absorption of optical radiation could enhance the tumouricidal effect of the phototherapy via the stimulation of PhP-640 formation. 


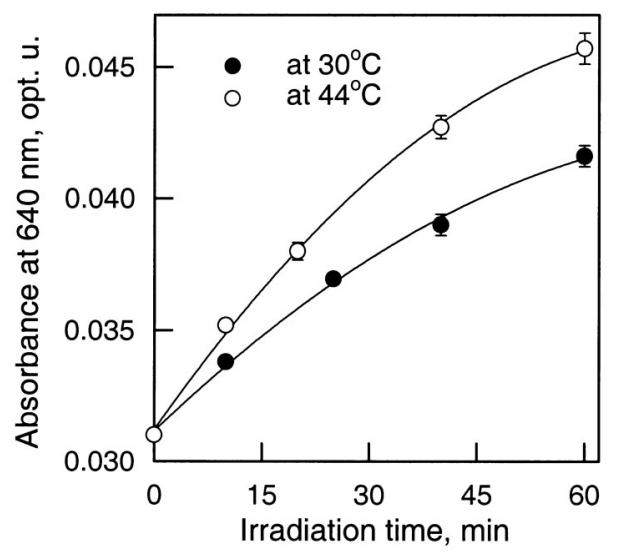

Fig. 11. The effect of heating on the formation of photoproduct-640 during irradiation of HPD aqueous solutions with red light at $630 \mathrm{~nm}$. The samples contained $10 \mu \mathrm{g} / \mathrm{mL}$ HPD and $0.2 \mathrm{mM}$ tryptophan in PBS. These measurements were performed in $2 \times 2 \mathrm{~cm}$ quartz cuvettes. Bars, SE.

\section{CONCLUSIONS}

Although PDT utilizing HPD or Photofrin-II as photosensitizing agents has already proved its usefulness in the treatment of cancer, the fundamental mechanisms of its antitumour effects remain poorly studied as yet. First, it concerns the nature of the ROS, which could be responsible for the HPD-PDT-induced tumour cell eradication. Previous studies concerning the aspect in the mechanism of the action of HPD-PDT have been inconclusive; some indicate ${ }^{1} \mathrm{O}_{2}$ as the main damaging agent, whereas others suggest the participation of oxygen radicals. However, in this work we clearly demonstrated that $\mathrm{H}_{2} \mathrm{O}_{2}, \mathrm{O}_{2}{ }^{-}$, and $\mathrm{OH}^{*}$ could mediate, along with ${ }^{1} \mathrm{O}_{2}$, the tumouricidal action of PDT with HPD. Our data suggest that in tumour cells treated with HPD-PDT the generation of $\mathrm{H}_{2} \mathrm{O}_{2}$ and oxygen radicals could be largely attributed to the photosensitized oxidation of cellular constituents (proteins and, probably, NAD(P)H). Another interesting finding of our studies is that in tumour cells subjected to HPD-PDT the Fenton-like reactions could play an important role in the generation of $\mathrm{OH}^{*}$. Furthermore, our experiments provided strong evidence that cellular $\mathrm{Cu} / \mathrm{Zn}-\mathrm{SOD}, \mathrm{CAT}$, and the glutathione redox cycle can protect tumour cells against the phototoxic action of HPD.

Earlier investigations on the mechanism of HPD-PDT showed that during PDT a significant increase in the temperature of tumour tissues may happen and that the heating potentiates the porphyrin-mediated photodestruction of neoplasms. However, until now the mechanism of the phenomenon remained unclear. Our results support the view that in laser photochemotherapy the mild hyperthermia (around $44^{\circ} \mathrm{C}$ ) produced by irradiation can enhance synergistically the HPD-photoinduced tumour eradication. A noteworthy observation of the present study is also 
that the potentiating effect of heating on HPD-photosensitized killing of tumour cells may take place at temperatures below hyperthermic. Our data indicate that the potentiating effect of heating, associated with photoirradiation, on the efficiency of PDT with HPD could be largely explained via heat-induced increases in the formation of cytotoxic ROS, such as $\mathrm{H}_{2} \mathrm{O}_{2}, \mathrm{O}_{2}{ }^{-}$, and $\mathrm{OH}^{*}$. In addition, our experiments showed that photosensitization of tumour cells by HPD causes an inactivation of cell-bound CAT and GPX, and that heat stress sensitized the $\mathrm{H}_{2} \mathrm{O}_{2}$-detoxifying enzymes to HPD-photoinduced inactivation; upon HPD-PDT, these events could result in loss of protection against accumulating $\mathrm{H}_{2} \mathrm{O}_{2}$. Our findings suggest that during clinical PDT, employing a $630 \mathrm{~nm}$ laser light to activate HPD, an increase in the temperature of tumour tissues could enhance the tumouricidal effect of the therapy via the stimulation of a chlorin-type photoproduct formation that possesses photosensitizing activity.

\section{REFERENCES}

Aebi, H. 1984. Catalase in vitro. Methods Enzymol., 105, 121-126.

Athar, M., Mukhtar, H., Elmets, C. A., Zaim, M. T., Lloyd, J. R. \& Bickers, D. R. 1988. In situ evidence for the involvement of superoxide anions in cutaneous porphyrin photosensitization. Biochem. Biophys. Res. Commun., 151, 1054-1059.

Bailey, H. H. 1998. L-S,R-buthionine sulfoximine: historical development and clinical issues. Chem. Biol. Interact., 111-112, 239-254.

Bensasson, R. V., Land, E. J. \& Truscott, T. G. 1993. Excited States and Free Radicals in Biology and Medicine. Oxford University Press, New York.

Berns, M. W., Coffey, J. \& Wile, A. G. 1984. Laser photoradiation therapy of cancer: possible role of hyperthermia. Lasers Surg. Med., 4, 87-92.

Bodaness, R. S. \& Chan, P. G. 1977. Singlet oxygen as a mediator in the hematoporphyrin-catalyzed photooxidation of NADPH to $\mathrm{NADP}^{+}$in deuterium oxide. J. Biol. Chem., 252, 8554-8560.

Buettner, G. R. \& Hall, R. D. 1987. Superoxide, hydrogen peroxide and singlet oxygen in hematoporphyrin derivative-cysteine, -NADH and -light systems. Biochim. Biophys. Acta, 923, 501-507.

Chance, B., Sies, H. \& Boveris, A. 1979. Hydroperoxide metabolism in mammalian organs. Physiol. Rev., 59, 527-605.

Chekulayev, V., Shevchuk, I. \& Chekulayeva, L. 1998. Effects of light exposure on the uptake and destruction of hematoporphyrin derivative in Ehrlich carcinoma cell suspension. Proc. Estonian Acad. Sci. Chem., 47, 73-91.

Chekulayeva, L., Shevchuk, I., Chekulayev, V. \& Jäälaid, R. 2002. Kinetic studies on the mechanism of haematoporphyrin derivative photobleaching. Proc. Estonian Acad. Sci. Chem., 51, 49-70.

Das, M., Mukhtar, H., Greenspan, E. R. \& Bickers, D. R. 1985. Photoenhancement of lipid peroxidation associated with the generation of reactive oxygen species in hepatic microsomes of hematoporphyrin derivative-treated rats. Cancer Res., 45, 6328-6330.

Dikalov, S., Khramtsov, V. \& Zimmer, G. 1996. Determination of rate constants of the reactions of thiols with superoxide radical by electron paramagnetic resonance: critical remarks on spectrophotometric approaches. Arch. Biochem. Biophys., 326, 207-218.

Dougherty, T. J. 2002. An update on photodynamic therapy applications. J. Clin. Laser Med. Surg., 20, 3-7. 
Edwards, P. G. 1988. Evidence that glutathione may determine the differential cell-cycle phase toxicity of a platinum (IV) antitumor agent. JNCI, 80, 734-738.

Evans, S., Matthews, W., Perry, R., Frankel, D. \& Norton, J. 1990. Effects of photodynamic therapy on tumor necrosis factor production by murine macrophages. JNCI, 82, 34-39.

Flanagan, S. W., Moseley, P. L. \& Buettner, G. R. 1998. Increased flux of free radicals in cells subjected to hyperthermia: detection by electron paramagnetic resonance spin trapping. FEBS Lett., 431, 285-286.

Giniunas, L., Rotomskis, R., Smilgevicius, V., Piskarskas, A., Didziapetriene, J., Bloznelyte, L. \& Griciute, L. 1991. Activity of haematoporphyrin derivative photoproduct in photodynamic therapy in vivo. Lasers Med. Sci., 6, 425-428.

Girotti, A. W. \& Thomas, J. P. 1984. Damaging effects of oxygen radical on resealed erythrocyte ghosts. J. Biol. Chem., 259, 1744-1752.

Golab, J., Nowis, D., Skrzycki, M., Czeczot, H., Baranczyk-Kuzma, A., Wilczynski, G. M., Makowski, M., Mroz, P., Kozar, K., Kaminski, R., Jalili, A., Kopec, M., Grzela, T. \& Jakobisiak, M. 2003. Antitumor effects of photodynamic therapy are potentiated by 2-methoxyestradiol. A superoxide dismutase inhibitor. J. Biol. Chem., 278, 407-414.

Goldstein, S. \& Czapski, G. 1984. Mannitol as an $\mathrm{OH}^{*}$ scavenger in aqueous solution and in biological systems. Int. J. Radiat. Biol., 46, 725-729.

Gottfried, V. \& Kimel, S. 1991. Temperature effects on photosensitized processes. J. Photochem. Photobiol. B: Biol., 8, 419-430.

Gutteridge, J. M. C. 1981. Thiobarbituric acid-reactivity following iron-dependent free-radical damage to amino acids and carbohydrates. FEBS Lett., 128, 343-346.

Hariharan, P. V., Courtney, J. \& Eleczko, S. 1980. Production of hydroxyl radicals in cell systems exposed to haematoporphyrin and red light. Int. J. Radiat. Biol., 37, 691-694.

Harris, L. R., Cake, M. H. \& Macey, D. J. 1994. Iron release from ferritin and its sensitivity to superoxide ions differs among vertebrates. Biochem. J., 301, 385-389.

Heikkila, R. E., Cabbat, F. S. \& Cohen, G. 1976. In vivo inhibition of superoxide dismutase in mice by diethyldithiocarbamate. J. Biol. Chem., 251, 2182-2185.

Henderson, B. W., Busch, T. M., Vaughan, L. A., Frawley, N. P., Babich, D., Sosa, T. A., Zollo, J. D., Dee, A. S., Cooper, M. T., Bellnier, D. A., Greco, W. R. \& Oseroff, A. R. 2000. Photofrin photodynamic therapy can significantly deplete or preserve oxygenation in human basal cell carcinomas during treatment, depending on fluence rate. Cancer Res., 60, 525-529.

Hetzel, F. W., Chen, H. \& Chen, Q. 1994. Tumor response and oxygenation after combined PDT and hyperthermia. Int. J. Radiat. Oncol. Biol. Phys., 30, 312.

Hildebrandt, B., Wust, P., Ahlers, O., Dieing, A., Sreenivasa, G., Kerner, T., Felix, R. \& Riess, H. 2002. The cellular and molecular basis of hyperthermia. Crit. Rev. Oncol./Hematol., 43, 33-56.

Hissin, P. J. \& Hilf, R. 1976. A fluorometric method for determination of oxidized and reduced glutathione in tissues. Anal. Biochem., 74, 214-226.

Issels, R. D., Fink, R. M. \& Lengfelder, E. 1986. Effects of hyperthermic conditions on the reactivity of oxygen radicals. Free Radical Res. Commun., 2, 7-18.

Jones, G. C., Kinsey, J. H., Neel, H. B. \& Cortese, D. A. 1984. The effect of cooling on the photodynamic action of hematoporphyrin derivative during interstitial phototherapy of solid tumors. Otolaryngol. Head Neck Surg., 92, 532-536.

Karu, T. 1999. Primary and secondary mechanisms of action of visible to near-IR radiation on cells. J. Photochem. Photobiol. B: Biol., 49, 1-17.

Kessel, D., Thompson, P., Musselman, B. \& Chang, C. K. 1987. Chemistry of hematoporphyrinderived photosensitizers. Photochem. Photobiol., 46, 563-568.

Keston, A. S. \& Brandt, R. 1965. The fluorometric analysis of ultramicro quantities of hydrogen peroxide. Anal. Biochem., 11, 1-5. 
Kinsey, J. H., Cortese, D. A. \& Neel, H. B. 1983. Thermal considerations in murine tumor killing using hematoporphyrin derivative phototherapy. Cancer Res., 43, 1562-1567.

Leunig, M., Leunig, A., Lankes, P. \& Goetz, A. E. 1994. Evaluation of photodynamic therapyinduced heating of hamster melanoma and its effect on local tumour eradication. Int. J. Hyperthermia, 10, 297-306.

Li, J. J. \& Oberley, L. W. 1997. Overexpression of manganese-containing superoxide dismutase confers resistance to the cytotoxicity of tumor necrosis factor alpha and/or hyperthermia. Cancer Res., 57, 1991-1998.

Lohmann, W. \& Paul, E. 1988. In situ detection of melanomas by fluorescence measurements. Naturwissenschaften, 75, 201-202.

Lord-Fontaine, S. \& Averill, D. A. 1999. Enhancement of cytotoxicity of hydrogen peroxide by hyperthermia in Chinese hamster ovary cells: role of antioxidant defenses. Arch. Biochem. Biophys., 363, 283-295.

Mang, T. S. 1990. Combination studies of hyperthermia induced by the neodymium: yttriumaluminum-garnet (Nd:YAG) laser as an adjuvant to photodynamic therapy. Lasers Surg. Med., 10, 173-178.

Mang, T. S., Dougherty, T. J., Potter, W. R., Boyle, D. G., Somer, S. \& Moan, J. 1987. Photobleaching of porphyrins used in photodynamic therapy and implications for therapy. Photochem. Photobiol., 45, 501-506.

Mao, Y., Zang, L. \& Shi, X. 1995. Singlet oxygen generation in the superoxide reaction. Biochem. Mol. Biol. Int., 36, 227-232.

Margoliash, E., Novogrodsky, A. \& Schejter, A. 1962. Irreversible reaction of 3-amino-1,2,4-triazole and related inhibitors with the protein and catalase. Biochem. J., 74, 339-348.

Matsumoto, N., Saito, H., Miyoshi, N., Nakanishi, K. \& Fukuda, M. 1990. Combination effect of hyperthermia and photodynamic therapy on carcinoma. Arch. Otolaryngol. Head Neck Surg., 116, 824-829.

Mattiello, J., Hetzel, F. \& Vandenheede, L. 1987. Intratumor temperature measurements during photodynamic therapy. Photochem. Photobiol., 46, 873-879.

Moan, J. 1984. The photochemical yield of singlet oxygen from porphyrins in different states of aggregation. Photochem. Photobiol., 39, 445-449.

Moan, J., Pettersen, E. O. \& Christensen, T. 1979. The mechanism of photodynamic inactivation of human cells in vitro in the presence of haematoporphyrin. Br. J. Cancer, 39, 398-407.

Nathan, C. F., Arrick, B. A., Murray, H. W., DeSantis, N. M. \& Cohn, Z. A. 1981. Tumor cell antioxidant defenses. Inhibition of the glutathione redox cycle enhances macrophage-mediated cytolysis. J. Exp. Med., 153, 766-782.

Oberley, L. W. \& Spitz, D. R. 1984. Assay of superoxide dismutase activity in tumour tissue. Methods Enzymol., 105, 457-464.

Orenstein, A., Kostenich, G., Kopolovic, Y., Babushkina, T. \& Malik, Z. 1999. Enhancement of ALA-PDT damage by IR-induced hyperthermia on a colon carcinoma model. Photochem. Photobiol., 69, 703-707.

Paglia, D. E. \& Valentine, W. N. 1967. Studies on the quantitative and qualitative characterization of erythrocyte glutathione peroxidase. J. Lab. Clin. Med., 70, 158-169.

Petrat, F., Pindiur, S., Kirsch, M. \& de Groot, H. 2003. "Mitochondrial" photochemical drugs do not release toxic amounts of ${ }^{1} \mathrm{O}_{2}$ within the mitochondrial matrix space. Arch. Biochem. Biophys., 412, 207-215.

Pinto, R. E. \& Bartley, W. 1969. The effect of age and sex on glutathione reductase and glutathione peroxidase activities and on aerobic glutathione oxidation in rat liver homogenates. Biochem. $J ., 112,109-115$.

Pottier, R. \& Truscott, T. G. 1986. The photochemistry of haematoporphyrin and related systems. Int. J. Radiat. Biol., 50, 421-452. 
Prinsze, C., Dubbelman, T. M. \& van Steveninck, J. 1991. Potentiation of thermal inactivation of glyceraldehyde-3-phosphate dehydrogenase by photodynamic treatment. A possible model for the synergistic interaction between photodynamic therapy and hyperthermia. Biochem. $J ., 276,357-362$.

Rothe, G. \& Valet, G. 1990. Flow cytometric analysis of respiratory burst activity in phagocytes with hydroethidine and 2',7'-dichlorofluorescin. J. Leukocyte Biol., 47, 440-448.

Rotomskis, R., Bagdonas, S. \& Streckyte, G. 1996. Spectroscopic studies of photobleaching and photoproduct formation of porphyrins used in tumour therapy. J. Photochem. Photobiol. B: Biol., 33, 61-67.

Rougee, M., Bensasson, R. V., Land, E. J. \& Pariente, R. 1988. Deactivation of singlet molecular oxygen by thiols and related compounds, possible protectors against skin photosensitivity. Photochem. Photobiol., 47, 485-489.

Salo, D. C., Donovan, C. M. \& Davies, K. J. 1991. HSP70 and other possible heat shock or oxidative stress proteins are induced in skeletal muscle, heart, and liver during exercise. Free Radical Biol. Med., 11, 239-246.

Sedlak, J. \& Lindsay, R. H. 1968. Estimation of total, protein-bound, and nonprotein sulfhydryl groups in tissue with Ellman's reagent. Anal. Biochem., 25, 192-205.

Shevchuk, I. N., Chekulayev, V. A. \& Chekulayeva, L. V. 2002. The role of lipid peroxidation and protein degradation in the photodestruction of Ehrlich ascites carcinoma cells sensitized by hematoporphyrin derivative. Exp. Oncol., 24, 216-224.

Szatrowski, T. P. \& Nathan, C. F. 1991. Production of large amounts of hydrogen peroxide by human tumor cells. Cancer Res., 51, 794-798.

Star, W. M., Marijnissen, H. P., van den Berg-Blok, A., Versteeg, J. A., Franken, K. A. \& Reinhold, H. S. 1986. Destruction of rat mammary tumor and normal tissue microcirculation by hematoporphyrin derivative photoradiation observed in vivo in sandwich observation chambers. Cancer Res., 46, 2532-2540.

Stohs, S. J. \& Bagchi, D. 1995. Oxidative mechanisms in the toxicity of metal ions. Free Radical Biol. Med., 18, 321-336.

Svaasand, L. O., Doiron, D. R. \& Dougherty, T. J. 1983. Temperature rise during photoradiation therapy of malignant tumors. Med. Phys., 10, 10-17.

Tanielian, C., Schweitzer, C., Mechin, R. \& Wolff, C. 2001. Quantum yield of singlet oxygen production by monomeric and aggregated forms of hematoporphyrin derivative. Free Radical Biol. Med., 30, 208-212.

Tarr, M. \& Valenzeno, D. P. 2003. Singlet oxygen: the relevance of extracellular production mechanisms to oxidative stress in vivo. Photochem. Photobiol. Sci., 2, 355-361.

Thomas, J. P. \& Girotti, A. W. 1989. Role of lipid peroxidation in hematoporphyrin derivativesensitized photokilling of tumor cells: protective effects of glutathione peroxidase. Cancer Res., 49, 1682-1686.

Udenfriend, S., Stein, S., Böhlen, P., Dairman, W., Leimgruber, W. \& Weigele, M. 1972. Fluorescamine: a reagent for assay of amino acids, peptides, proteins, and primary amines in the picomole range. Science, 178, 871-872.

Uehara, M., Inokuchi, T. \& Sano, K. 1996. Experimental study of combined hyperthermic and photodynamic therapy on carcinoma in the mouse. J. Oral. Maxillofac. Surg., 54, 729736.

Watkins, M. T., Patton, G. M., Soler, H. M., Albadawi, H., Humphries, D. E., Evans, J. E. \& Kadowaki, H. 1999. Synthesis of 8-epi-prostaglandin $F_{2}$ alpha by human endothelial cells: role of prostaglandin $\mathrm{H}_{2}$ synthase. Biochem. J., 344, 747-754.

Weishaupt, K. R., Gomer, C. J. \& Dougherty, T. J. 1976. Identification of singlet oxygen as the cytotoxic agent in photo-inactivation of a murine tumor. Cancer Res., 36, 2326-2329. 


\title{
Hematoporfüriini derivaadi fototoksilise toime mehhanismist kasvajarakkudel
}

\author{
Ljudmilla Tšekulajeva, Igor Ševtšuk ja Vladimir Tšekulajev
}

\begin{abstract}
Uurimuses on hinnatud singletsest hapnikust $\left({ }^{1} \mathrm{O}_{2}\right)$ erinevate hapniku reaktiivsete osakeste (HRO) osalust hematoporfüriini derivaadi (HPD) manulusel fotodünaamilise teraapia (FDT) vähivastases toimes ja selgitatud temperatuuri mõju FDT toime mehhanismile. Saadud tulemused annavad alust arvata, et $\mathrm{H}_{2} \mathrm{O}_{2}$ ja hapniku radikaalid etendavad tähtsat osa HPD-FDT kasvajavastases toimes. Ehrlichi astsiidse kartsinoomi (EAC) rakkude kiiritamine HPD manulusel tingib olulistes kogustes $\mathrm{H}_{2} \mathrm{O}_{2}$, superoksiidi $\left(\mathrm{O}_{2}^{-}\right)$ja hüdroksüül- $\left(\mathrm{OH}^{*}\right)$ radikaalide teket, mis nagu ${ }^{1} \mathrm{O}_{2}$ on kaasatud rakkude fotoinaktivatsiooni protsessi in vitro. $\mathrm{Cu} / \mathrm{Zn}$ superoksiidi dismutaas, katalaas ja glutatiooni redokstsükkel on võimelised kaitsma rakke HPD fototoksilise toime eest. Saadud andmed toetavad seisukohta, et kiiritamise käigus esinev pehme hüpertermia $\left(44^{\circ} \mathrm{C}\right)$ võib sünergistlikult HPD kasvajavastast toimet suurendada. Temperatuuri tõus kiiritamisel $30-44^{\circ} \mathrm{C}$ põhjustas olulise $(\sim 1,5$-kordse) rakkude HPD fotohävimiskiiruse suurenemise, samas oli ainult hüpertermia $\left(44^{\circ} \mathrm{C}\right)$ toksiline mõju rakkudele väike. Saadud tulemused annavad alust arvata, et kiiritamisel võib kudede soojenemise soodustav mõju HPD-FDT vähivastasele toimele olla seotud tsütotoksiliste $\mathrm{HRO} \mathrm{H}_{2} \mathrm{O}_{2}, \mathrm{O}_{2}{ }^{\bullet}$ ja $\mathrm{OH}^{*}$ tekkega. Lisaks langes katsetes oluliselt katalaasi ja glutatiooni peroksüdaasi aktiivsus ning termiline stress suurendas $\mathrm{H}_{2} \mathrm{O}_{2}$ lagundavate ensüümide tundlikkust HPD fotoindutseeritud inaktivatsioonile. Seega võivad need nähtused vähendada rakkude kaitset HPD-FDT käigus tekkiva $\mathrm{H}_{2} \mathrm{O}_{2}$ vastu. Uuringust tuleneb, et HPD-FDT käigus võib kasvajakoe temperatuuri tõus tõhustada teraapia efektiivsust tänu kloriin-tüüpi fotoprodukti tekke stimulatsioonile.
\end{abstract}

